\title{
Angiotensin II-induced TLR4 mediated abdominal aortic aneurysm in apolipoprotein E knockout mice is dependent on STAT3
}

\section{Citation}

Qin, Zhexue, Jessamyn Bagley, Galina Sukhova, Wendy E. Baur, Ho-Jin Park, Debbie Beasley, Peter Libby, Yali Zhang, and Jonas B. Galper. 2015. “Angiotensin II-Induced TLR4 Mediated Abdominal Aortic Aneurysm in Apolipoprotein E Knockout Mice Is Dependent on STAT3." Journal of Molecular and Cellular Cardiology 87 (October): 160-170. doi:10.1016/j.yjmcc.2015.08.014.

\section{Published Version}

10.1016/j.yjmcc.2015.08.014

\section{Permanent link}

http://nrs.harvard.edu/urn-3:HUL.InstRepos:23032813

\section{Terms of Use}

This article was downloaded from Harvard University's DASH repository, and is made available under the terms and conditions applicable to Open Access Policy Articles, as set forth at http:// nrs.harvard.edu/urn-3:HUL.InstRepos:dash.current.terms-of-use\#OAP

\section{Share Your Story}

The Harvard community has made this article openly available.

Please share how this access benefits you. Submit a story.

Accessibility 


\section{Angiotensin II-induced TLR4 mediated abdominal aortic aneurysm in Apolipoprotein E knockout mice is dependent on STAT3}

Zhexue Qin ${ }^{1,2}$, Jessamyn Bagley ${ }^{1}$, Galina Sukhova ${ }^{3}$, Wendy E. Baur ${ }^{1}$, Ho-Jin Park ${ }^{1}$, Debbie Beasley ${ }^{1}$, Peter Libby ${ }^{3}$, Yali Zhang ${ }^{1,5}$, and Jonas B. Galper ${ }^{1,4,5}$

${ }^{1}$ Molecular Cardiology Research Institute, Tufts Medical Center and Tufts University School of Medicine, Boston, MA, 02111

${ }^{2}$ Dr. Qin's current address: Department of Cardiology, Xinqiao Hospital, Third Military Medical University, Chongqing, 400037, China

${ }^{3}$ Cardiovascular Division, Department of Medicine, Brigham and Women's Hospital and Harvard Medical School, Boston, MA, 02113

${ }^{4}$ Cardiovascular Center, Division of Cardiology, Department of Medicine, Tufts Medical Center and Tufts University School of Medicine, Boston MA 02111

${ }^{5}$ Corresponding authors: Yali Zhang, Molecular Cardiology Research Institute, Tufts Medical Center, 750 Washington St. Boston MA, USA Tel. 617-636-9003; E-mail yzhang2@tuftsmedicalcenter.org; Jonas B. Galper, 750 Washington St. Boston MA, Tel. 617-636-9004, E-mail jgalper@tuftsmedicalcenter.org 


\begin{abstract}
Abdominal Aortic Aneurysm (AAA) is a major cause of mortality and morbidity in men over 65 years of age. Male apolipoprotein $E$ knockout $\left(\mathrm{ApoE}^{-/}\right)$mice infused with angiotensin II (Angll) develop AAA. Although Angll stimulates both JAK/STAT and Tolllike receptor 4 (TLR4) signaling pathways, their involvement in Angll mediated AAA formation is unclear. Here we used the small molecule STAT3 inhibitor, S3I-201, the TLR4 inhibitor Eritoran and ApoE ${ }^{-1} \mathrm{TLR}^{-/-}$mice to evaluate the interaction between STAT3 and TLR4 signaling in Angll-induced AAA formation. ApoE ${ }^{-/}$mice infused for 28 days with Angll developed AAAs and increased STAT3 activation and TLR4 expression. Moreover, Angll increased macrophage infiltration and the ratio of M1 (proinflammatory)/M2 (healing) macrophages in aneurysmal tissue as early as 7-10 days after Angll infusion. STAT3 inhibition with S3I-201 decreased the incidence and severity of Angll-induced AAA formation and decreased MMP activity and the ratio of M1/M2 macrophages. Furthermore, Angll-mediated AAA formation, MMP secretion, STAT3 phosphorylation and the ratio of $\mathrm{M} 1 / \mathrm{M} 2$ macrophages were markedly decreased in $\mathrm{ApoE}^{-/} \mathrm{TLR}^{-/-}$mice, and in Eritoran-treated ApoE ${ }^{-/-}$mice. TLR4 and pSTAT3 levels were also increased in human aneurysmal tissue. These data support a role of pSTAT3 in TLR4 dependent AAA formation and possible therapeutic roles for TLR4 and/or STAT3 inhibition in AAA.
\end{abstract}

Key words: abdominal aortic aneurysm, toll-like receptor 4, STAT3, angiotensin II 


\section{Introduction}

Abdominal aortic aneurysm (AAA) affects about $8 \%$ of men over the age of 65 years in the US, with an annual mortality of more than 15,000.[1-3] Currently, surgical open repair and endovascular repair with stenting remain the only treatment for AAA. Although several molecular mechanisms have been implicated in the pathogenesis of AAA,[4] pathways susceptible to medical therapy that may limit or inhibit aneurysm progression have not been validated.

The development of AAAs in response to Angiotensin II (Angll) in $\mathrm{ApoE}^{-/-}$mice is a widely accepted animal model for AAA formation. In this model the early events in aneurysm formation involve accumulation of inflammatory cells in the adventitia either via recruitment of circulating monocytes or the proliferation of resident macrophages.[57] Macrophages exist in several subsets with distinct functions. M1 macrophages mediate pro-inflammatory responses while M2 macrophages exert anti-inflammatory effects and regulate wound healing.[8] M1 macrophages release and activate matrix metalloproteinases (MMPs) which can degrade extracellular matrix and elastic laminae and thus promote dilatation of the lumen and thrombus formation.[5] The combination of the inflammatory response, degradation of extracellular matrix constituents including elastin, and resulting alterations of blood flow and the development ischemia due to thrombus formation result in cellular loss and can promote rupture of the aortic wall.

The Toll-like receptor (TLR) family of molecular pattern recognition receptors serves as cellular sensors for both pathogen-derived and endogenous danger-associated molecular patterns. TLR activation results in rapid recruitment of inflammatory cells and the local production of pro-inflammatory mediators. TLR4 promotes atherosclerosis in mouse models $[9,10]$ and has recently been implicated in AAA formation.[11]

The Janus Kinase/Signal Transducer and Activator of Transcription (JAK/STAT) pathway transduces a multitude of signals involved in development, homeostasis and inflammation.[12] Ligand binding to receptors activates JAK and STAT proteins which are phosphorylated and form homo or heterodimers which then translocate into the nucleus where they regulate gene expression.[12] In mammals, the JAK/STAT pathway transduces signals for a wide array of cytokines and growth factors including Angll, TNF- $\alpha$, IL-1 $\beta$, IL- 6 and IFN- $\gamma$ all of which have been implicated in AAA formation.[13-15] Stimulation of IL- 6 and IL-1 production by bacterial lipopolysaccharide (LPS), a TLR4 agonist, in a macrophage cell line is decreased after treatment with either a STAT3 inhibitor or after silencing with a STAT3 siRNA consistent with a role for STAT3 in TLR4 signaling.[16] The role of the JAK/STAT pathway in TLR4 signaling and Angll-mediated AAA formation is, however, unclear. Here we demonstrate that Angll-mediated AAA formation potentiates expression of TLR4 and increases the ratio of M1/M2 macrophages in the abdominal aorta via a STAT3 dependent pathway. Pharmacological inhibition of TLR4 or STAT3 markedly attenuates the incidence and severity of AAAs in Angll-treated $\mathrm{ApoE}^{-/-}$mice suggesting a role of STAT3 dependent TLR4 signaling in the pathogenesis of AAA formation.

\section{Methods}

An expanded Methods section can be found in the supplemental materials.

\subsection{Mice}


Male $\mathrm{ApoE}^{-/-}$mice on a $\mathrm{C57 \textrm {BL } / 6 \mathrm { J }}$ background were obtained from The Jackson Laboratory (Bar Harbor, ME) and bred in a pathogen-free environment. ApoE ${ }^{-/}$and $\mathrm{TLR}^{-/}$mice were crossbred to obtain ApoE ${ }^{-/} \mathrm{TLR}^{-/-}$double knockout mice.[9] Four month-old male mice were used for all experiments. All mice were maintained on a normal mouse chow diet. Animal care and the experimental procedures were carried out in accordance with National Institute of Health guidelines and approved by the Tufts Institutional Animal Care and Use Committee.

\subsection{Drug treatment}

Alzet osmotic minipumps (Model 2004, Durect, CA, USA) were implanted into $\mathrm{ApoE}^{-/}$or $\mathrm{ApoE}^{-/} \mathrm{TLR}^{-/-}$mice to deliver $750 \mathrm{ng} / \mathrm{kg} / \mathrm{min}$ of Angll (Phoenix Pharmaceuticals, Inc.) subcutaneously for 28 days.[5, 17] Placebo, STAT3 inhibitor S3I-201 (5 mg/kg, i.p., every other day, Selleckchem) or TLR4 antagonist Eritoran $(0.3 \mathrm{mg} / \mathrm{kg}$, i.v., every other day, Eisai Inc.) were given for 28 days. S3I-201 inhibits STAT3 phosphorylation with an $\mathrm{IC}_{50}=86 \mu \mathrm{M}$. The dose of S3I-201 was based on the dose of the drug that inhibited STAT3 dependent growth of breast tumor cells in mice treated every other day for 15 days.[18] The dose of Eritoran was based on the daily i.v. bolus required to maintain blood levels at 50-100 ng/mL over 2 days and to inhibit the increase in TNFa levels in mice treated with LPS.[19]

\subsection{Determination of blood pressure and lipids}

Systolic blood pressures and lipids were measured as described.[17]

\subsection{Classification of aneurysms and measurement of aortic diameter}

The aorta was exposed under a dissecting microscope, and the peri-adventitial tissue was removed. Aneurysm severity was rated from Type I to IV according to the method of Daugherty et al.[20]: Type I, dilated lumen without thrombus; Type II, remodeled aneurysmal tissue with little thrombus; Type III, a pronounced bulbous form of Type II with thrombus; Type IV, multiple, often overlapping aneurysms containing thrombus. The outer diameter of the suprarenal aorta was measured with a caliper.

\subsection{Tissue harvesting}

After the aorta was exposed, the aneurysmal segment of the aorta was harvested, snap frozen in liquid nitrogen, and then stored at $-80^{\circ} \mathrm{C}$ pending further processing for western blot and quantitative RT-PCR (qPCR) analysis. Human aneurysmal specimens were routinely discarded tissues obtained from patients at the time of AAA repair or from normal donors. All specimens were obtained by protocols approved by the Human Investigation Review Committee at Brigham and Women's Hospital.[21]

\subsection{Western Blotting}

Tissue was taken for analysis from the suprarenal aorta and included the aneurysm if present. Protein lysates were obtained from the corresponding regions of aneurysmal tissue. Western blot analysis was performed as previously described.[17] The Tyr705 specific pSTAT3 and total STAT3 antibodies were obtained from Cell Signaling Technology; the TLR4 and GAPDH antibodies were obtained from Santa Cruz 
Biotechnology. The protein bands were visualized using chemiluminescent substrates (Pierce).

\subsection{Histology}

Perfusion-fixed aortas were embedded in paraffin, cut in cross-section (5 10 $\mu \mathrm{m})$ and stained with hematoxylin and eosin (H\&E) and Verhoeff-van Gieson (VVG) for elastin.

\subsection{Gelatin Zymography}

MMP-2 and MMP-9 activities in homogenates of aortic tissue or conditioned media from cell cultures were determined by zymography as previously described.[22]

\subsection{Scoring of elastin breaks and aortic wall thickness}

Elastin integrity was graded after VVG staining as described pevioulsy. [23] Wall thickness was measured on cross sections from aorta through all three layers of the aortic wall: intima, media, and adventitia.[24]

\subsection{Isolation of RNA and quantitative RT-PCR}

RNA was isolated using an RNeasy Mini Kit (Qiagen) according to the manufacturer's instructions. One microgram of RNA sample was then used for reverse transcription and synthesis of cDNA using the Superscript III First-Strand system (Invitrogen). Quantitative real-time PCR was performed on a Mastercycler ep realplex ${ }^{2}$ (Eppendorf) using SYBR Green PCR Master Mix (Qiagen). GAPDH expression was used as internal reference in all PCR experiments. RT-PCR primers (Supplemental Table III) for specific target genes were designed based on their reported sequences and synthesized by the Tufts University Core Facility.

\subsection{Mouse bone marrow derived macrophages (BMDMs)}

BMDMs were used as an in vitro model for studies of the mechanism of macrophage regulation in response to Angll. BMDMs were obtained by flushing the femurs from either $\mathrm{ApoE}^{-/-}$or $\mathrm{ApoE}^{-/-} \mathrm{TLR}^{-/-}$mice. Cells were cultured as previously described,[25] and BMDMs were treated with Angll $(0.25-2 \mu \mathrm{M})$ or LPS $(10 \mathrm{ng} / \mathrm{mL}$, List Biological Laboratories Inc., CA) for 16 hours. The medium was collected for MMP assay, and cell lysates for western blot analysis.

\subsection{Mouse vascular smooth muscle cells (VSMCs)}

Aortic VSMCs from each of five $\mathrm{ApoE}^{-/}$or $\mathrm{ApoE}^{-1-} \mathrm{TLR}^{-/-}$mice were obtained by the explant method as described previously.[26] Cultured cells were identified as VSMCs by immunostaining for smooth muscle-specific a-actin according to the manufacturer's instructions (Sigma Chemical Co.).

\section{$\underline{2.13}$ Flow cytometry analysis}

Aortas were harvested as described and digested following the method of Galkina et al.[27] Detailed information can be found in the supplemental materials. Cells were filtered, and cell surface staining was performed as previously described[28] using anti- 
CD11b (M1/70, BD Pharmingen), anti-CD11c (HL3, BD Pharmingen), anti-CD206 (CO68C2 Biolegend), anti-MHC class II (MS114.15.2, eBioscience), anti-F4/80 (BM8 eBioscience), anti-CD90 (30H12, eBioscience), anti-DX5 (BD Pharmingen), anti-NK1.1 (BD Pharmingen), anti-B220 (RA3-6B2, BD Pharmingen) and anti-Ly6G (1A8, Biolegend). Cellular fluorescence was analyzed using a FacsCanto II cytometer (BD Biosciences, San Jose CA), and data were analyzed using FlowJo software (Tree Star, Inc. Ashland OR).

\section{$\underline{2.14}$ Statistical analysis}

Data are presented as mean \pm SEM. To assess statistical significance, the KolmogorovSmirnov test with Lilliefors' correction was first employed to determine normal distribution. Levene's test was used to test for equality of variances. The student's t-test or Mann-Whitney U test were used for comparison between two groups. Three group' comparisons were carried out using one-way ANOVA (LSD Post-hoc test) or the nonparametric Kruskal-Wallis test. To assess statistical significance of aneurysm subtype variables, cross-tabulated contingency tables were constructed and likelihood ratio Chisquare statistics, $L R$ were computed. If $L R s$ demonstrated significant differences in the aneurysm severity between treatment groups, then Cramer's $V$ and Goodman and Kruskal Tau tests were performed to assess the strength of the association. $P<0.05$ was considered statistically significant. All analyses were performed with IBM SPSS Statistics 19.0 (IBM Inc., NY).

\section{Results}

\subsection{STAT3 inhibition attenuates the incidence and severity of Angll-induced AAA formation}

To test the hypothesis that the JAK/STAT pathway participates in Angll-induced AAA formation in $\mathrm{ApoE}^{-/-}$mice, the level of pSTAT3 in abdominal aortas of Angll and placebo-treated $\mathrm{ApoE}^{-/-}$mice was compared. Angll treatment resulted in a $2.18 \pm 0.12$ fold increase $(n=4, p<0.01)$ in the phosphorylation of STAT3 at Tyr705, while total STAT3 (tSTAT3) levels increased by $1.60 \pm 0.12$ fold $(p<0.05$, Figure $1 \mathrm{~A}$ and $1 \mathrm{~B})$. The increase in total STAT3 in association with increased pSTAT3 is consistent with data demonstrating regulation of STAT3 expression by pSTAT3 dimers.[29] Most importantly, the ratio of pSTAT3/tSTAT3 increased by $1.57 \pm 0.06$ fold $(n=4, p<0.01)$. The small molecule STAT3 inhibitor S3I-201 binds with high specificity to the SH2 domain of STAT3, interfering with dimerization and DNA binding.[18] To determine whether the increase in PSTAT3 contributed to the pathogenesis of Angll-induced AAA formation, $\mathrm{ApoE}^{-/-}$mice were treated with either S3I-201 or vehicle. Continuous infusion with S3I201 significantly reduced the incidence of AAA formation from $84 \%$ in the placebotreated group $(n=19)$ to $40 \%$ in the S3I-201 treated group $(n=15, p<0.05)$ (Fig. 1C). Based on the classification system of Daugherty et al.[20] S3I-201 also decreased the severity of the aneurysms (Fig. 1D, supplemental Fig. S1 and supplemental Table I). The distribution of aneurysms was significantly different between the 2 treatment groups as determined by the Likelihood Ratio $\square^{2}$ test $(p=0.009)$, the Goodman and Kruskal Tau test, and the Cramer's $V$ test, $p<0.05$ for each (Supplemental Table I). Furthermore, the maximal external diameter of the aorta was also significantly decreased from 
$1.84 \pm 0.14 \mathrm{~mm}$ in placebo-treated mice $(\mathrm{n}=19)$ to $1.16 \pm 0.07 \mathrm{~mm}$ in the $S 3 \mathrm{I}-201$ treated group $(n=15, p<0.01)$ (Fig. 1E). Western blot analysis confirmed that treatment of mice with S3I-201 decreased the ratio of pSTAT3/tSTAT3 in Angll-induced aneurysms from $3.65 \pm 0.28(n=4)$ to $1.16 \pm 0.11(n=4, p<0.01)$ fold increase vs. normal aorta (Fig. 1F, G). S3I-201 had no effect on body weight, plasma cholesterol concentration or systolic blood pressure (Supplemental Table II).

3.2 STAT3 inhibition attenuates aortic wall remodeling, elastin degradation and suppresses macrophage infiltration and MMP activity in Angll treated ApoE ${ }^{-/-}$mice.

H\&E staining of cross sections taken from the suprarenal region of the aorta demonstrated that Angll treatment resulted in a marked thickening of the abdominal aortic wall. Both the maximal wall thickness and the minimal wall thickness were markedly increased in Angll treated mice, while S3I-201 treatment reduced both maximum and minimum wall thicknesses (Table I, Fig. 2A). Furthermore, treatment with S3I-201 significantly decreased elastin degradation in AAA lesions of Angll-infused ApoE $^{-1-}$ mice from grade $1.54 \pm 0.09, n=18$ to grade $0.99 \pm 0.10, \quad(n=16, p<0.01)$ respectively (Fig. $2 \mathrm{~A}$ and $\mathrm{B}$ ), where Elastin integrity of VVG stained sections was graded as: grade 0, no interruption in the medial elastic laminae; grade 1, noticeable interruption in the medial elastic laminae without change of luminal shape; grade 2. prolonged disruption in the elastic laminae with bulbous extension of the aortic lumen.

Table I

Elastin score and wall thickness in $\mathrm{ApoE}^{-/}$mice treated with Angll, S3I-201, and in Angll treated $\mathrm{ApoE}^{-/-} \mathrm{TLR}^{-/-}$mice

\begin{tabular}{ccccc}
\hline & \multicolumn{3}{c}{ ApoE $^{-/}$} & ApoE $^{-/} \mathrm{TLR}^{-/-}$ \\
\hline & $\begin{array}{c}\text { Control } \\
(\mathrm{n}=6)\end{array}$ & $\begin{array}{c}\text { Angll } \\
(\mathrm{n}=12)\end{array}$ & $\begin{array}{c}\text { Angll+S3I-201 } \\
(\mathrm{n}=12)\end{array}$ & $\begin{array}{c}\text { Angll } \\
(\mathrm{n}=6)\end{array}$ \\
\hline Elastin score & N.A & $1.540 \pm 0.090$ & $0.990 \pm 0.100^{\#}$ & $1.075 \pm 0.025^{\#}$ \\
$\begin{array}{l}\text { Wall thickness } \\
\text { (Maximal, mm) }\end{array}$ & $0.073 \pm 0.017$ & $1.315 \pm 0.1698^{\star *}$ & $0.271 \pm 0.109^{\# \#}$ & $0.390 \pm 0.076^{\# \#}$ \\
$\begin{array}{l}\text { Wall thickness } \\
(\text { Minimal, mm) }\end{array}$ & $0.004 \pm 0.004$ & $0.219 \pm 0.078^{* *}$ & $0.037 \pm 0.021^{\# \#}$ & $0.074 \pm 0.045^{\# \#}$ \\
\hline
\end{tabular}

All results are expressed as mean \pm SEM. ${ }^{* *} P<0.01$ compared with control, ${ }^{\#} P<0.05$ and \#\# $P<0.01$ compared with Angll group.

In order to determine the role of STAT3 in macrophage infiltration of aneurysmal tissues, $\mathrm{CD} 11 \mathrm{~b}^{+} \mathrm{Lin}^{-} \mathrm{F} 4 / 80^{+}$cells were measured by flow cytometry. As shown in Fig. $2 \mathrm{C}$, Angll infusion promoted macrophage infiltration by $19.75 \pm 1.65$-fold $(n=5, p<0.01$ vs. control group), and treatment with S3I-201 decreased macrophage infiltration to $9.59 \pm 2.58$-fold $(n=5, p<0.01$ vs. the Angll group). These data are consistent with the well-established role of macrophages in the development of AAAs. Although the source of macrophages in aneurysmal tissue is unclear[2], BMDMs were used as an in vitro model to study the direct effects of Angll on a specific cell type found in the aneurysm. Stimulation with 
Angll increased pSTAT3 levels in BMDMs from $\mathrm{ApoE}^{-/-}$mice in a dose-dependent manner with a $1.38 \pm 0.05$ fold $(n=3)$ increase at $0.25 \mu \mathrm{M}$, and a maximal effect of $3.23 \pm 0.15$ fold $(n=3, p<0.05)$ at $0.5 \mu \mathrm{M}$ (Supplemental Fig. S2).

MMPs contribute to the initiation and progression of AAA formation,[30] particularly MMP2 and MMP9 which were increased in the abdominal aortas of Angll-treated ApoE' - mice.[17, 31, 32] To determine whether Angll stimulation of MMP secretion was dependent on PSTAT3, the effect of S3I-201 on MMP2 and MMP9 activity in suprarenal aortas of Angll-treated ApoE $^{-/-}$mice was measured. S3I-201 treatment significantly down-regulated MMP9 activity ( $9.50 \pm 0.65$ vs. $1.73 \pm 0.31$ fold in Angll and Angll+S3I-201 treated mice, respectively), and MMP2 activity $(5.10 \pm 0.28$ vs. $1.73 \pm 0.14$ fold, $n=4$, $\mathrm{p}<0.01$ ) (Fig. 2D and $\mathrm{E}$ ).

Vascular smooth muscle cells are a major component of the aortic wall and have been implicated in synthesis of extracellular matrix, protease activity and recruitment of inflammatory cells.[33] To further establish the role of STAT3 in AAA formation, we used VSMCs as a second in vitro model to study the role of PSTAT3 in the pathogenesis of AAAs. VSMCs were starved in DMEM for 8 hours followed by treatment with $0.5 \mu \mathrm{M}$ Angll for 16 hours. S3I-201 $(100 \mu \mathrm{M})$ or vehicle was added 1 hour prior to Angll. Cells were harvested for western blot analysis and medium for zymographic analysis. pSTAT3 levels increased $1.89 \pm 0.08$ fold, while MMP2 levels increased $1.69 \pm 0.12$ fold $(n=4, P<0.05)$, while treatment with S3I-201 completely reversed this effect (Supplementary Fig. S3).

\subsection{The ratio of M1/M2 macrophages is increased in Angll-induced AAA formation and STAT3 inhibition markedly reverses M1 polarization}

At least 2 subsets of macrophages have been described based on functional phenotype. Pro-inflammatory M1 macrophages are characterized by the cell surface marker CD11c, high surface expression of MHC class II and the intracellular marker iNOS. "Healing" M2 macrophages are characterized by the cell surface marker CD206 and intracellular marker Ym-1. Flow cytometry analysis based on the cell surface markers was used to determine the M1 and M2 subtypes (Supplemental Fig. S4). Since no combination of cell surface markers is able to unequivocally identify M1/M2 macrophages, qPCR analysis for expression of iNOS and Ym-1 was further used to validate flow cytometry data.

In order to determine whether macrophage infiltration and macrophage phenotype play a role in the early events of AAA formation, the suprarenal aortas from $\mathrm{ApoE}^{-/}$mice 7-10 days after Angll treatment were used for flow cytometry. At this time point only 2 out of 16 mice $(13 \%)$ developed AAAs. Flow cytometric analysis of the suprarenal aortas from 6 of these mice with no visible evidence of AAAs demonstrated a $2.91 \pm 0.45$ fold increase $(n=6, p<0.01)$ in total macrophages compared to control as determined by CD11 $\mathrm{b}^{+} \mathrm{Lin}^{-} \mathrm{F} 4 / 80^{+}$cells (Fig. $3 \mathrm{~A}$ ). Importantly, the ratio of $\mathrm{M} 1 / \mathrm{M} 2$ was significantly increased by $3.07 \pm 0.82$ fold $(n=6, p<0.05$, Fig. $3 A)$. These data supported the conclusion that macrophage accumulation and an increase in the ratio of $\mathrm{M} 1 / \mathrm{M} 2$ phenotype are early pro-inflammatory events in AAA formation. Furthermore, after 28 days of Angll treatment, total macrophages increased $19.75 \pm 1.65$ fold compared to control (Fig. $2 \mathrm{C}$ ), while the ratio of M1/M2 macrophages increased $5.87 \pm 0.73$ fold ( $n=4$, $\mathrm{p}<0.01$, Fig. 3B and C). Importantly, S3I-201 treatment not only markedly decreased 
total macrophage infiltration (Fig. $2 \mathrm{C}$ ) but also significantly decreased the ratio of $\mathrm{M} 1 / \mathrm{M} 2$ macrophages to $2.93 \pm 0.34$ fold $(n=5, p<0.01)$ above control (Fig. $3 B$ and $C)$. These findings were further supported by qPCR analysis of mRNA levels of iNOS, an M1 marker and $\mathrm{Ym}-1$, an M2 marker. Angll infusion increased iNOS mRNA expression in aneurysmal tissue $66.87 \pm 5.80$ fold $(n=4, p<0.01)$ above the control, while treatment with S3I-201 decreased iNOS mRNA level to $12.76 \pm 3.58$ fold above control $(n=4, p<0.01)$. Conversely, Angll infusion decreased $Y m-1$ mRNA to $0.44 \pm 0.11$ fold $(n=4, p<0.01)$, while S3I-201 treatment increased $Y m-1$ to $1.24 \pm 0.32$ fold $(n=4, p<0.01)$. Additionally the ratio of iNOS/Ym-1 increased $145.44 \pm 22.42$ fold $(n=4, p<0.01)$ in response to Angll, but increased to only $9.65 \pm 3.51(n=4, p<0.01)$ in response to Angll plus S3I-201 treatment (Fig. 3D). These data supported the conclusion that the Angll mediated increase in pro-inflammatory macrophages in the suprarenal aortas of $\mathrm{ApoE}^{-/-}$mice was dependent at least in part on pSTAT3.

\subsection{Angll up-regulates the expression of TLR4}

Recent evidence supports a role of TLR4 signaling in the pathogenesis of Angll-induced aortic aneurysms in $\mathrm{LDLR}^{-/-}$mice.[11] To further investigate the role of TLR4 in Angllinduced AAA formation, we determined whether TLR4 expression was increased in aneurysms in these mice. TLR 4 mRNA level determined by qPCR were $4.76 \pm 0.72$ fold higher $(n=5, p<0.01)$ in the suprarenal aorta of Angll treated mice compared with control (Fig. 4A). Furthermore, western blot analysis demonstrated that TLR4 protein level was also increased $1.78 \pm 0.15$ fold $(n=4, p<0.05)$ in Angll-treated mice compared to control (Fig. 4B and C). To validate this effect of Angll on macrophages in vitro, we determined the effect of Angll on TLR4 levels in BMDMs. Data outlined in Supplemental Fig. S5 demonstrate that Angll increased TLR4 protein expression in BMDMs from Apo: ${ }^{-/-}$mice in a dose-dependent manner.

\subsection{TLR4 deficiency attenuates Angll-induced pSTAT3}

Angll mediated AAA formation had been shown to be dependent on TLR4[11]. Here we determined whether Angll mediated activation of STAT3 was also dependent on TLR4. We determined the effect of Angll treatment on AAA formation in an ApoE ${ }^{-/}$TLR4 $^{-/-}$ mouse. The incidence and severity of AAA formation were both significantly reduced in $\mathrm{ApoE}^{-/} \mathrm{TLR}^{-/-}$mice compared to the $\mathrm{ApoE}^{-/-}$controls (Fig. 4D and E). AAA incidence decreased from $80 \%$ in $\mathrm{ApoE}^{-/}$mice $(n=20)$ to $39 \%$ in $\mathrm{ApoE}^{-/} \mathrm{TLR}^{-/-}$mice $(n=18$, $\mathrm{p}<0.05)$. AAA severity also decreased in Angll treated $\mathrm{ApoE}^{-/} \mathrm{TLR}^{-/-}$mice compared with $\mathrm{ApoE}^{-/}$mice: $65 \%$ of $\mathrm{ApoE}^{-/-}$mice treated with Angll developed either type III or type IV aneurysms compared with $17 \%$ of $\mathrm{ApoE}^{-/} \mathrm{TLR}^{-/-}$mice (Fig. 4E, Supplemental Table I). The distribution of aneurysms was significantly different between the 2 treatment groups as determined by the Likelihood Ratio $\square^{2}$ test $(p=0.002)$, the Goodman and Kruskal Tau test, and the Cramer's $V$ test, $\mathrm{p}<0.007$ for each (Supplemental Table I). In addition, the maximal aortic diameter decreased from $1.89 \pm 0.18 \mathrm{~mm}(\mathrm{n}=20)$ in $\mathrm{ApoE}^{-/-}$mice to $1.26 \pm 0.20 \mathrm{~mm}(\mathrm{n}=18, \mathrm{p}<0.05)$ in $\mathrm{ApoE}^{-/-} \mathrm{TLR}^{-/-}$ mice (Fig. 4F). Furthermore, the elastin score decreased significantly in the suprarenal aorta of the Angll treated $\mathrm{ApoE}^{-1 /} \mathrm{TLR}^{-/-}$mouse compared to the Angll treated ApoE ${ }^{-/-}$ mice (Table I, Supplemental Fig. S6). Similarly, both maximal and minimal aortic wall thickness were significantly decreased in the $\mathrm{ApoE}^{-1-T L R 4^{-/-}}$mice compared with the 
ApoE $^{-/-}$(Table I, Supplemental Fig. S6) consistent with a marked decrease in aneurysm severity. Additionally, TLR4 deficiency resulted in a significant down-regulation of Angll stimulated MMP9 and MMP2 activity (Fig. 5A, B). Systolic blood pressure, serum cholesterol level and body weight did not differ significantly between $\mathrm{ApoE}^{-/-}$and $\mathrm{ApoE}^{-/-}$ $\mathrm{TLR}^{-/-}$mice (Supplemental Table II).

Finally to determine whether the increase in PSTAT3 found in Angll-induced aneurysms is dependent on TLR4 signaling, we compared levels of STAT3 phosphorylation in homogenates of the suprarenal aortas from Angll-treated $\mathrm{ApoE}^{-/-}$and $\mathrm{ApoE}^{-/} \mathrm{TLR}^{-/-}$mice. Knockout of TLR4 resulted in a decrease in Angll-mediated pSTAT3 from $2.64 \pm 0.15$ fold above control to $1.56 \pm 0.30$ fold $(n=4, p<0.01$, Fig. $5 \mathrm{C}$ and D) consistent with a role of TLR4 in pSTAT3-mediated AAA formation. The link between TLR4 and Angll-induced pSTAT3 is further supported by the finding that treatment of BMDMs from $\mathrm{ApoE}^{-/}$mice with either Angll or LPS increased pSTAT3 levels, by $6.41 \pm 2.48$ fold $(n=3, p<0.05)$ and $12.17 \pm 1.99$ fold $(n=3, p<0.05)$ respectively. Neither Angll nor LPS had an effect on pSTAT3 in BMDMs from ApoE ${ }^{-/} \mathrm{TLR}^{-/-}$(Fig. 5E and F). The role of TLR4 in AAA formation is further supported by the finding that Angll mediated STAT3 activation and MMP2 secretion in VSMCs cultured from ApoE ${ }^{-/-}$mice, was abolished by TLR4 deficiency (Fig. S7).

\subsection{TLR4 deficiency attenuates the Angll-induced increase in M1/M2 ratio}

To determine whether the Angll-induced increase in M1 macrophages and M1/M2 ratio were dependent on TLR4 signaling, the effect of Angll on macrophage phenotypes in the suprarenal aortas of $A p o E^{-1 /} \mathrm{TLR}^{-/-}$mice was determined by $\mathrm{qPCR}$ analysis. TLR4 deficiency in Angll treated mice decreased iNOS expression from 47.20 \pm 21.21 fold above control $(n=4, p<0.01)$ in $A_{p o E^{-/}}$mice to $5.76 \pm 0.53$ fold $(n=4, p<0.01)$ above control in $\mathrm{ApoE}^{-/-} \mathrm{TLR}^{-/-}$mice consistent with a marked decrease in M1 phenotype in the $\mathrm{TLR}^{-/-}$mouse. Conversely, compared to control, TLR4 deficiency in Angll treated mice increased $\mathrm{Ym}-1$ expression from $0.75 \pm 0.19$ fold $(n=4, p<0.05)$ in $\mathrm{ApoE}^{-/}$mice to $2.85 \pm 0.66$ fold $(n=4, p<0.01)$ in $\mathrm{ApoE}^{-/} \mathrm{TLR}^{-/-}$mice consistent with an increase in the M2 phenotype. Additionally the ratio of iNOS/Ym-1 in Angll-treated mice decreased from 85.27 \pm 50.48 fold $(n=4, p<0.05)$ above control in $A_{p o E^{-/-}}$mice to 2.12 $\pm 0.59(n=4$, $\mathrm{p}<0.05$, Fig. 5E) in ApoE ${ }^{-/} \mathrm{TLR}^{-/-}$mice.

\subsection{Eritoran, a small molecule TLR4 Inhibitor, attenuates Angll-induced AAA formation, STAT3 stimulation, MMP activity and M1/M2 ratio}

Given data supporting a role of TLR4 in Angll-induced AAA formation,[11] we determined whether TLR4 inhibitors might have therapeutic potential in the treatment of AAAs. A number of small molecule TLR4 inhibitors have been developed for the treatment of sepsis, including Eritoran (Eisai, Inc.).[34] To determine the effect of pharmacologic inhibition of TLR4 on aneurysm formation, ApoE ${ }^{-/}$mice receiving continuous Angll infusion were treated with either placebo or Eritoran $(300 \mu \mathrm{g} / \mathrm{kg}$, i.v.) every other day. Eritoran treatment decreased the incidence of AAA formation from $80 \%$ to $44 \%$ ( $n=10$ and 9 respectively, Fig. 6A). AAA severity also decreased in Eritoran treated mice compared with placebo treated: $60 \%$ of placebo-treated mice developed either type III or type IV aneurysms compared with $33 \%$ of mice that developed type III aneurysms while no type IV aneurysms were found in Eritoran-treated mice. Eritoran 
treatment also significantly reduced maximal aortic diameter from $1.91 \pm 0.18 \mathrm{~mm}(\mathrm{n}=10)$ to $1.35 \pm 0.19 \mathrm{~mm}(\mathrm{n}=9, \mathrm{p}<0.05)$ (Fig. $6 \mathrm{~B})$. Eritoran had no effect on body weight, plasma cholesterol and systolic blood pressure (Supplemental Table II).

Additionally, Eritoran treatment significantly down-regulated Angll-stimulated MMP9 activity from $16.39 \pm 1.64$ to $1.62 \pm 0.30$ fold and MMP2 activity from $7.80 \pm 0.43$ to $2.19 \pm 0.76$ fold respectively above those in control mice $(n=4, p<0.01$, Fig. $6 C$ and $D)$. Furthermore, Eritoran significantly attenuated Angll-stimulated pSTAT3 levels from $3.08 \pm 0.56$ fold to $1.76 \pm 0.36$ fold compared with control $(n=4, p<0.05)$ (Fig. $6 E$ and F) and inhibited the Angll-mediated increase in M1/M2 ratio. The mRNA level of iNOS significantly decreased from $39.65 \pm 8.10$ to $8.49 \pm 0.54$ fold $(n=4, p<0.01$ ), while the mRNA level of $Y m-1$ increased from $0.48 \pm 0.12$ to $1.23 \pm 0.34$ fold $(n=4, p<0.05)$ in Eritoran treated mice. Finally, the ratio of iNOS/Ym-1 decreased from $105.21 \pm 40.94$ to $7.20 \pm 1.45$ fold $(n=4, p<0.01)$ by Eritoran (Fig. $6 G)$.

\subsection{Increased TLR4 expression and STAT3 activation in human AAAs}

In order to test the potential clinical relevance of our findings, the levels of TLR4 and PSTAT3 in human AAA tissue were measured. Aortic aneurysmal tissue taken from AAA patients at the time of open surgical repair demonstrated significantly higher levels of TLR4, pSTAT3 and tSTAT3 $1.99 \pm 0.25,2.04 \pm 0.08$ and $1.22 \pm 0.02$ fold respectively, compared to aortic tissue from normal donors without AAA $(n=4, p<0.05$, Fig. $7 A$ and $B)$.

\section{Discussion}

These data support the conclusion that the incidence and severity of Angll-induced AAA formation in $\mathrm{ApoE}^{-/-}$mice depends at least in part on the Angll-mediated activation of STAT3. Furthermore, the finding that both Angll-mediated AAA formation and STAT3 phosphorylation are markedly attenuated in $\mathrm{ApoE}^{-/-} \mathrm{TLR}^{-/-}$mice and in $\mathrm{ApoE}^{-/-}$mice treated with the TLR4 inhibitor Eritoran strongly supports the conclusion that Angll stimulates STAT3, by mechanisms that involve TLR4 signaling (Fig. 7C). The finding that Angll markedly increased macrophage infiltration in the suprarenal aorta with a predominant increase in the ratio of pro-inflammatory M1 macrophages to antiinflammatory/healing M2 macrophages at an early time point (7-10 days after Angll infusion) when there is little anatomical evidence of AAA formation, is consistent with the conclusion that macrophage infiltration is an early event in AAA formation, and that M1 macrophages may play an early role in the pathogenesis of AAAs in this model. After 28 days of Angll infusion, at a time when $84 \%$ of animals develop AAA, we observe a further increase in both the extent of macrophage infiltration and an increase in the ratio of M1/M2 macrophages. Importantly the increase in the M1/M2 ratio at day 28 was reversed by inhibition of either STAT3 or TLR4 signaling. The observed increase in M1/M2 macrophages may be due to proliferation of resident macrophages or macrophage differentiation of circulating monocytes after infiltration of the aortic wall. Furthermore, recent data suggest that everolimus, an mTOR inhibitor, attenuated M1 polarization in $\mathrm{ApoE}^{-/-}$BMDMs in vitro and AAA formation in vivo.[35] The choice of BMDM as an in vitro model for changes observed in the intact suprarenal aorta is complicated by a recent bone marrow transplant study in which donor marrow from cholesterol fed $\mathrm{LDLR}^{-/} \mathrm{TLR}^{-/-}$mice had no effect on the increase in aortic diameter in cholesterol fed $\mathrm{LDLR}^{-/-}$recipient mice treated with high doses of Angll.[11] However, 
given that increased levels of macrophages is well established in the pathogenesis of AAA, whether these cells migrated from the spleen, the bone marrow or represent proliferation of resident macrophages, does not preclude the use of BMDM as an in vitro model for studies of the mechanism of macrophages regulation in response to Angll. Using BMDM, we determined that the levels of PSTAT3 and TLR4 were dose dependently increased in response to Angll. Given the preponderance of VSMCs in the wall of the aorta and data supporting a role of VSMCs in AAA formation[33], we used VSMCs as second in vitro model. Data demonstrated that increased pSTAT3 and MMP secretion in VSMCs in response to Angll which was dependent on TLR4 signaling further supporting the validity of the conclusions derived from homogenates of the suprarenal aortas.

The role of TLR4 in the pathogenesis of AAAs is supported by recent data demonstrating a decreased incidence of AAA formation in cholesterol fed LDLR $^{-/}$TLR4 ${ }^{-}$ ${ }^{1-}$ mice treated with Angll.[11] Here we demonstrate that the incidence and severity of AAA formation were markedly decreased in Angll-treated $\mathrm{ApoE}^{-/-}$that were TLR4deficient, or were treated with a small molecule TLR4 inhibitor. Furthermore the finding that stimulation of STAT3 phosphorylation in response to both Angll and LPS was markedly attenuated in BMDM from ApoE ${ }^{-/}$TLR4 $^{-/-}$mice further support the role of TLR4 in STAT3 mediated AAA formation. The finding that TLR4 expression is increased in the suprarenal aorta of Angll treated $\mathrm{ApoE}^{-/-}$mice and that Angll dose dependently increased TLR4 expression in $\mathrm{BMDM}$ from $\mathrm{ApoE}^{-/}$mice is consistent with a potentiation of TLR4 signaling in response to Angll. Recently, Greenhill et al. demonstrated that mice with hyper-expression of the IL6 cytokine receptor subunit gp130 are hyperresponsive to the TLR4 ligand LPS.[36] This effect was significantly attenuated in STAT3 $^{-/}$gp130 overexpressing mice indicating a role of STAT3 in TLR4 signaling. However, in another study, STAT3 knockdown potentiated TLR4 dependent ischemia/reperfusion injury in mouse liver.[37] These data suggest pleiotropic effects of STAT3 potentiating or attenuating TLR4 signaling in different disease models. Importantly, treatment of $A p o E^{-/-}$mice with Eritoran not only significantly decreased the incidence and severity of AAAs, but also interfered with Angll-mediated secretion of MMPs and the accumulation of M1 macrophages in the suprarenal aortas of $A p o E^{-/-}$ mice consistent with a potential therapeutic role for TLR4 inhibitors in the treatment of AAAs.

Although the role of the JAK/STAT pathway in Angll signaling is supported by studies which demonstrate the binding of JAK2 to angiotensin receptor 1 and the activation of STAT1 and STAT2 in vascular smooth muscle cells[13] and the activation of STAT3 in rat cardiomyocytes,[38] its role in the pathogenesis of AAAs is unclear. Our data demonstrate a role for Angll in the activation of STAT3 in the pathogenesis of AAAs. Specifically, S3I-201, a small molecule inhibitor with a high degree of specificity for STAT3, which interferes with dimerization of STAT3,[18] markedly decreased both the incidence and severity of AAAs, MMP secretion, macrophage infiltration and M1/M2 ratio in an Angll-induced $\mathrm{ApoE}^{-/-}$mouse model. Recent data demonstrating the association of a variant of the IL-6 receptor with decreased incidence of AAAs and decreased expression of STAT3,[39] further suggested a role of STAT3 in AAA formation. Furthermore, in a recent study aged C57BL/6 mice treated with very high doses of Angll $(2500 \mathrm{ng} / \mathrm{kg})$ developed aortic dilatation that was attenuated by a STAT3 
inhibitor peptide.[40] Consistent with these findings, our data demonstrated a marked elevation of pSTAT3 and total STAT3, as well as TLR4 in tissue samples obtained from patients during AAA repair compared with levels in non-aneurysmal aortic tissue from organ donors. These data are consistent with the findings of a recent study demonstrating increased pSTAT3 in patients with AAAs.[41] Interestingly, in a different model of Angll mediated AAA formation in which C57BL/6 wild-type mice were treated with neutralization antibody to TGF $\beta$, selective deletion of STAT3 in macrophages and neutrophils did not affect aneurysm development.[42] These differences likely reflect differences in the mechanisms of TGF $\beta$ effects on AAA formation

Our study demonstrates roles of both STAT3 and TLR4 signaling in Angll-mediated AAA formation. The role of STAT3 in the pathogenesis of AAAs is further supported by data demonstrating that STAT3 activation is necessary for Angll-stimulated MMP secretion and the increase in total macrophages and the ratio of MI/M2 macrophages in suprarenal aortas of $\mathrm{ApoE}^{-/-}$mice. The findings that inhibition of TLR4 signaling by Eritoran and inhibition of STAT3 signaling by S3I-201 significantly decreased the incidence and severity of AAA formation in this mouse model suggest that both TLR4 and STAT3 might serve as therapeutic targets in the treatment of AAAs.

\section{Supplementary material}

Supplementary material is available online

\section{Funding}

This study was supported by NIH T32 HL69770 to Dr. Zhang, NIH grants 1R01HL066467 to Dr. Galper, HL47569 and HL113732 to Dr. Beasley and National Natural Science Foundation of China 31301167 to Dr. Qin.

\section{Acknowledgments}

We thank Eisai Pharmaceuticals for Eritoran

\section{Disclosures}

None. 


\section{References}

[1] Dua A, Kuy S, Lee CJ, Upchurch GR, Jr., Desai SS. Epidemiology of aortic aneurysm repair in the United States from 2000 to 2010. Journal of vascular surgery. 2014;59:1512-7.

[2] Daugherty A, Cassis LA. Mechanisms of abdominal aortic aneurysm formation. Current atherosclerosis reports. 2002;4:222-7.

[3] Upchurch GR, Jr., Schaub TA. Abdominal aortic aneurysm. American family physician. 2006;73:1198204.

[4] Nanda S, Sharma SG, Longo S. Molecular targets and abdominal aortic aneurysms. Recent patents on cardiovascular drug discovery. 2009;4:150-9.

[5] Daugherty A, Manning MW, Cassis LA. Angiotensin II promotes atherosclerotic lesions and aneurysms in apolipoprotein E-deficient mice. J Clin Invest. 2000;105:1605-12.

[6] Turner GH, Olzinski AR, Bernard RE, Aravindhan K, Boyle RJ, Newman MJ, et al. Assessment of macrophage infiltration in a murine model of abdominal aortic aneurysm. Journal of magnetic resonance imaging : JMRI. 2009;30:455-60.

[7] Nahrendorf M, Keliher E, Marinelli B, Leuschner F, Robbins CS, Gerszten RE, et al. Detection of macrophages in aortic aneurysms by nanoparticle positron emission tomography-computed tomography. Arterioscler Thromb Vasc Biol. 2011;31:750-7.

[8] Murray PJ, Wynn TA. Protective and pathogenic functions of macrophage subsets. Nature reviews Immunology. 2011;11:723-37.

[9] Higashimori M, Tatro JB, Moore KJ, Mendelsohn ME, Galper JB, Beasley D. Role of toll-like receptor 4 in intimal foam cell accumulation in apolipoprotein E-deficient mice. Arterioscler Thromb Vasc Biol. 2011;31:50-7.

[10] Vink A, Schoneveld AH, van der Meer JJ, van Middelaar BJ, Sluijter JP, Smeets MB, et al. In vivo evidence for a role of toll-like receptor 4 in the development of intimal lesions. Circulation. 2002;106:1985-90.

[11] Owens AP, 3rd, Rateri DL, Howatt DA, Moore KJ, Tobias PS, Curtiss LK, et al. MyD88 deficiency attenuates angiotensin II-induced abdominal aortic aneurysm formation independent of signaling through Toll-like receptors 2 and 4. Arterioscler Thromb Vasc Biol. 2011;31:2813-9.

[12] Rawlings JS, Rosler KM, Harrison DA. The JAK/STAT signaling pathway. Journal of cell science. 2004;117:1281-3.

[13] Garner JM, Fan M, Yang CH, Du Z, Sims M, Davidoff AM, et al. Constitutive activation of signal transducer and activator of transcription 3 (STAT3) and nuclear factor kappaB signaling in glioblastoma cancer stem cells regulates the Notch pathway. The Journal of biological chemistry. 2013;288:26167-76. [14] Xiong W, MacTaggart J, Knispel R, Worth J, Persidsky Y, Baxter BT. Blocking TNF-alpha attenuates aneurysm formation in a murine model. Journal of immunology. 2009;183:2741-6.

[15] Wassef M, Baxter BT, Chisholm RL, Dalman RL, Fillinger MF, Heinecke J, et al. Pathogenesis of abdominal aortic aneurysms: a multidisciplinary research program supported by the National Heart, Lung, and Blood Institute. Journal of vascular surgery. 2001;34:730-8.

[16] Samavati L, Rastogi R, Du W, Huttemann M, Fite A, Franchi L. STAT3 tyrosine phosphorylation is critical for interleukin 1 beta and interleukin- 6 production in response to lipopolysaccharide and live bacteria. Molecular immunology. 2009;46:1867-77.

[17] Zhang Y, Naggar JC, Welzig CM, Beasley D, Moulton KS, Park HJ, et al. Simvastatin inhibits angiotensin II-induced abdominal aortic aneurysm formation in apolipoprotein E-knockout mice: possible role of ERK. Arterioscler Thromb Vasc Biol. 2009;29:1764-71. 
[18] Siddiquee K, Zhang S, Guida WC, Blaskovich MA, Greedy B, Lawrence HR, et al. Selective chemical probe inhibitor of Stat3, identified through structure-based virtual screening, induces antitumor activity. Proceedings of the National Academy of Sciences of the United States of America. 2007;104:7391-6. [19] Wasan KM, Risovic V, Sivak O, Lee SD, Mason DX, Chiklis GR, et al. Influence of plasma cholesterol and triglyceride concentrations and eritoran (E5564) micelle size on its plasma pharmacokinetics and ex vivo activity following single intravenous bolus dose into healthy female rabbits. Pharmaceutical research. 2008;25:176-82.

[20] Daugherty A, Manning MW, Cassis LA. Antagonism of AT2 receptors augments angiotensin IIinduced abdominal aortic aneurysms and atherosclerosis. British journal of pharmacology.

2001;134:865-70.

[21] Schonbeck U, Sukhova GK, Gerdes N, Libby P. T(H)2 predominant immune responses prevail in human abdominal aortic aneurysm. The American journal of pathology. 2002;161:499-506.

[22] Herron GS, Werb Z, Dwyer K, Banda MJ. Secretion of metalloproteinases by stimulated capillary endothelial cells. I. Production of procollagenase and prostromelysin exceeds expression of proteolytic activity. The Journal of biological chemistry. 1986;261:2810-3.

[23] Schulte S, Sun J, Libby P, Macfarlane L, Sun C, Lopez-Ilasaca M, et al. Cystatin C deficiency promotes inflammation in angiotensin II-induced abdominal aortic aneurisms in atherosclerotic mice. The American journal of pathology. 2010;177:456-63.

[24] Shang EK, Lai E, Pouch AM, Hinmon R, Gorman RC, Gorman JH, 3rd, et al. Validation of semiautomated and locally resolved aortic wall thickness measurements from computed tomography. Journal of vascular surgery. 2015;61:1034-40.

[25] Weischenfeldt J, Porse B. Bone Marrow-Derived Macrophages (BMM): Isolation and Applications. CSH protocols. 2008;2008:pdb prot5080.

[26] Karas RH, Patterson BL, Mendelsohn ME. Human vascular smooth muscle cells contain functional estrogen receptor. Circulation. 1994;89:1943-50.

[27] Butcher MJ, Herre M, Ley K, Galkina E. Flow cytometry analysis of immune cells within murine aortas. Journal of visualized experiments : JoVE. 2011.

[28] Jindra PT, Tripathi S, Tian C, lacomini J, Bagley J. Tolerance to MHC class II disparate allografts through genetic modification of bone marrow. Gene therapy. 2013;20:478-86.

[29] Narimatsu M, Maeda H, Itoh S, Atsumi T, Ohtani T, Nishida K, et al. Tissue-specific autoregulation of the stat 3 gene and its role in interleukin-6-induced survival signals in T cells. Molecular and cellular biology. 2001;21:6615-25.

[30] Knox JB, Sukhova GK, Whittemore AD, Libby P. Evidence for altered balance between matrix metalloproteinases and their inhibitors in human aortic diseases. Circulation. 1997;95:205-12.

[31] Longo GM, Xiong W, Greiner TC, Zhao Y, Fiotti N, Baxter BT. Matrix metalloproteinases 2 and 9 work in concert to produce aortic aneurysms. J Clin Invest. 2002;110:625-32.

[32] Pyo R, Lee JK, Shipley JM, Curci JA, Mao D, Ziporin SJ, et al. Targeted gene disruption of matrix metalloproteinase-9 (gelatinase B) suppresses development of experimental abdominal aortic aneurysms. J Clin Invest. 2000;105:1641-9.

[33] Airhart N, Brownstein BH, Cobb JP, Schierding W, Arif B, Ennis TL, et al. Smooth muscle cells from abdominal aortic aneurysms are unique and can independently and synergistically degrade insoluble elastin. Journal of vascular surgery. 2014;60:1033-41; discussion 41-2.

[34] Kim HM, Park BS, Kim JI, Kim SE, Lee J, Oh SC, et al. Crystal structure of the TLR4-MD-2 complex with bound endotoxin antagonist Eritoran. Cell. 2007;130:906-17.

[35] Moran CS, Jose RJ, Moxon JV, Roomberg A, Norman PE, Rush C, et al. Everolimus limits aortic aneurysm in the apolipoprotein E-deficient mouse by downregulating $\mathrm{C}$-C chemokine receptor 2 positive monocytes. Arterioscler Thromb Vasc Biol. 2013;33:814-21. 
[36] Greenhill CJ, Rose-John S, Lissilaa R, Ferlin W, Ernst M, Hertzog PJ, et al. IL-6 trans-signaling modulates TLR4-dependent inflammatory responses via STAT3. Journal of immunology. 2011;186:1199208.

[37] Ke B, Shen XD, Ji H, Kamo N, Gao F, Freitas MC, et al. HO-1-STAT3 axis in mouse liver ischemia/reperfusion injury: regulation of TLR4 innate responses through PI3K/PTEN signaling. Journal of hepatology. 2012;56:359-66.

[38] Sano M, Fukuda K, Kodama H, Takahashi T, Kato T, Hakuno D, et al. Autocrine/Paracrine secretion of IL-6 family cytokines causes angiotensin II-induced delayed STAT3 activation. Biochemical and biophysical research communications. 2000;269:798-802.

[39] Harrison SC, Smith AJ, Jones GT, Swerdlow DI, Rampuri R, Bown MJ, et al. Interleukin-6 receptor pathways in abdominal aortic aneurysm. European heart journal. 2013;34:3707-16.

[40] Ju X, ljaz T, Sun H, Ray S, Lejeune W, Lee C, et al. Interleukin-6-signal transducer and activator of transcription-3 signaling mediates aortic dissections induced by angiotensin II via the T-helper lymphocyte 17-interleukin 17 axis in C57BL/6 mice. Arterioscler Thromb Vasc Biol. 2013;33:1612-21. [41] Liao M, Xu J, Clair AJ, Ehrman B, Graham LM, Eagleton MJ. Local and systemic alterations in signal transducers and activators of transcription (STAT) associated with human abdominal aortic aneurysms. The Journal of surgical research. 2012;176:321-8.

[42] Romain M, Taleb S, Dalloz M, Ponnuswamy P, Esposito B, Perez N, et al. Overexpression of SOCS3 in T lymphocytes leads to impaired interleukin-17 production and severe aortic aneurysm formation in mice--brief report. Arterioscler Thromb Vasc Biol. 2013;33:581-4. 


\section{Figure Legends}

Figure 1 The STAT3 inhibitor, S3I-201, decreases the incidence and severity of AAA formation. (A) Effect of Angll on pSTAT3 and tSTAT3 in aneurysmal tissues determined by western blotting. (B) Densitometric analysis of data in A normalized to GAPDH $\left({ }^{*} \mathrm{p}<0.05,{ }^{* *} \mathrm{p}<0.01\right.$ vs. control, $\mathrm{n}=4$ per group). (C) S3I-201 significantly reduced the incidence of AAA formation from $84 \%$ (Angll) to $40 \%(p<0.05, n=19$ and 15), (D) S3I201 significantly reduced the severity of AAA based on the classification of aneurysms. (E) The external diameter of the aorta was also significantly decreased by S3I-201 treatment ( ${ }^{\#} \mathrm{p}<0.01$ vs. placebo, $\mathrm{n}=19$ and 15), ( $F \&$ \&) S3I-201 decreased Angllinduced $p S T A T 3 /$ tSTAT3 determined by western blot $\left({ }^{* *} p<0.01\right.$ vs. control, ${ }^{\# \#} p<0.01$ vs. placebo, $n=4)$.

Figure 2 S3I-201 attenuates Angll-induced remodeling of the aortic wall, macrophage infiltration and MMP activity in the abdominal aortas. (A) Representative photomicrographs of aortic cross sections. Top, H\&E staining, bottom, VVG elastin staining. (B) Area defined by the square in $A$ demonstrating the elastin degradation. $(C)$ S3I-201 significantly decreased the total macrophage $\left(C D 11 b^{+} L_{i n}^{-} F 4 / 80^{+}\right)$infiltration in the abdominal aortas measured by flow cytometry. (D \& E) S3I-201 significantly decreased Angll-induced gelatinolytic activities of MMP2 and MMP9 in homogenates of the aortas determined by gelatin zymography $\left({ }^{* *} p<0.01\right.$ vs. control ${ }^{\# \#} p<0.01$ vs. placebo, $\mathrm{n}=4$ ).

Figure 3 The role of M1/M2 macrophages in Angll-induced AAA formation. (A) Total macrophage and $\mathrm{M} 1 / \mathrm{M} 2$ ratio measured by flow cytometry were increased at day 7-10 after Angll treatment $\left(n=6,{ }^{*} p<0.05,{ }^{* *} p<0.01\right.$ vs. control). (B) The ratio of M1/M2 was further increased by Angll treatment at day 28, while S3I-201 markedly decreased M1/M2 ratio ( $n=5,{ }^{* *} p<0.01$ vs. control, ${ }^{\# \#} p<0.01$ vs. placebo). (C) Representative plots illustrating identification of $\mathrm{M} 1$ macrophage $\left(\mathrm{CD} 11 \mathrm{c}^{+}\right)$, and $\mathrm{M} 2$ macrophage $\left(\mathrm{CD} 206^{+}\right)$in aortic digests. (D) The effects of Angll and S3I-201 on the expression of iNOS, Ym-1 mRNA and the ratio of iNOS $/ Y m-1\left(n=4,{ }^{* *} p<0.01\right.$ vs. control, ${ }^{\# \#} p<0.01$ vs. placebo).

Figure 4 Role of TLR4 in Angll-induced AAA formation in $\mathrm{ApoE}^{-/-}$mice. (A) Angll increased the mRNA level of TLR4 in suprarenal aorta determined by qPCR $\left({ }^{* *} p<0.01\right.$ vs. control, $n=4)$. ( $B \& C$ ) Angll increased TLR4 protein level determined by western blot analysis ( ${ }^{*} \mathrm{p}<0.05$ vs. control, $\mathrm{n}=4$ ). ( $D$ and $E$ ) Deficiency of TLR4 significantly reduced the incidence and severity of AAA formation in $\mathrm{ApoE}^{-/-}$mice $(\mathrm{p}<0.05, \mathrm{n}=18$ and 20 per group). ( $F$ ) The maximal aortic diameter was also significantly decreased by TLR4 deficiency ( ${ }^{*} \mathrm{p}<0.05$ vs. control, $\mathrm{n}=18$ and 20 per group, respectively).

Figure 5 TLR4 knockout attenuates Angll-induced pSTAT3 and the ratio of M1/M2. $(A \& B)$ TLR4 deficiency decreased Angll-induced pSTAT3 in aortic homogenates $\left({ }^{* * *} \mathrm{p}<0.001\right.$ vs. control, ${ }^{\# \#} \mathrm{p}<0.01$ vs. ApoE ${ }^{-/}+$Angll, $\left.\mathrm{n}=4\right)$. (C \& D) TLR4 deficiency attenuated Angll- and LPS- induced activation of pSTAT3 in BMDMs from ApoE ${ }^{-/}$mice determined by western blot analysis $\left({ }^{* *} p<0.01\right.$ vs. control, $\left.n=4\right)$. $(E)$ The effect of TLR4 
deficiency on iNOS, Ym-1 and the ratio of iNOS/Ym-1 mRNA levels $\left(n=4,{ }^{*} p<0.05\right.$ vs. control, ${ }^{\star \star} \mathrm{p}<0.01$ vs. control, ${ }^{\# \#} \mathrm{p}<0.01$ vs. ApoE ${ }^{-/}+$Angll).

Figure 6 The TLR4 inhibitor Eritoran decreases the incidence of Angll-induced AAAs, the activation of STAT3 and M1/M2 ratio. ( $A \& B$ ) Eritoran significantly reduced the incidence of Angll-induced AAA formation and the external diameter of the aortas $\left({ }^{*} p<0.05\right.$ vs. placebo, $n=9$ and 10 per group). ( $C \& D$ ) Eritoran decreased the gelatinolytic activities MMP2 and MMP9 in Angll-treated ApoE ${ }^{-/-}$mice measured by zymography in homogenates of aortas $\left({ }^{* *} p<0.01\right.$ vs. control, ${ }^{\#} p<0.01$ vs. placebo, $\left.n=4\right)$. $(E \& F)$ The activation of STAT3 induced by Angll was significantly decreased by Eritoran, as determined by western blot analysis of homogenates of aortas $\left({ }^{*} \mathrm{p}<0.05\right.$ vs. control, ${ }^{\#}<<0.05$ vs. placebo, $\left.n=4\right)$. (G) The effect of Eritoran on iNOS, $Y m-1$ and the ratio of iNOS $/ Y$ m- 1 mRNA levels, as measured by $\mathrm{qPCR}\left(\mathrm{n}=4,{ }^{*} \mathrm{p}<0.05\right.$, vs. control, ${ }^{* *} \mathrm{p}<0.01$ vs. control, ${ }^{\# \#} \mathrm{p}<0.01$ vs. placebo).

Figure 7 Abdominal aortas from patients with AAA demonstrate increased levels of TLR4, pSTAT3 and tSTAT3 compared to normal donor aortas. ( $A$ \& $B$ ) Western blot analysis of TLR4, pSTAT3, tSTAT3 in tissue homogenates of aortic tissue taken at the time of aneurysmal repair and aortas from normal organ donors $\left({ }^{*} \mathrm{p}<0.05 \mathrm{vs}\right.$. control, $\mathrm{n}=4$ ). (C) Schematic representation of proposed pathway for the link between STAT3 and TLR4 in Angll-induced of AAA formation. 

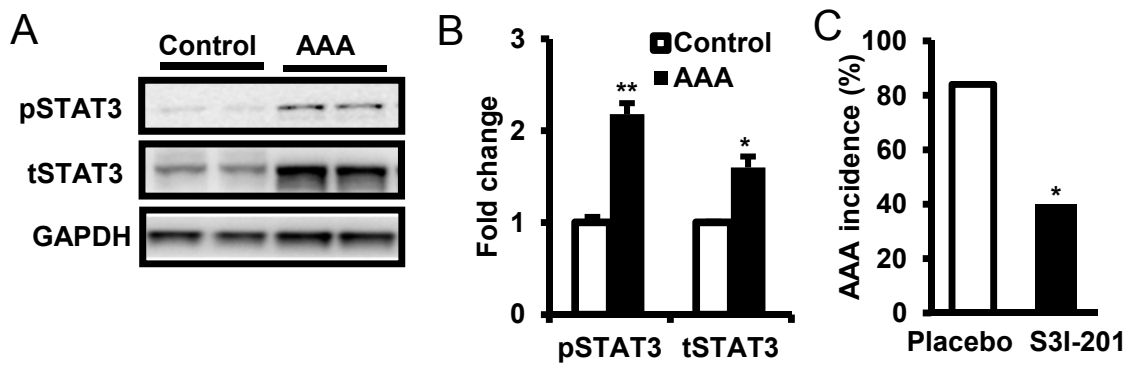

Fig.1

D

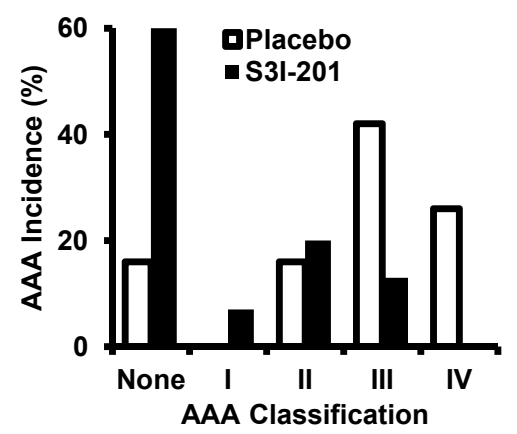

F

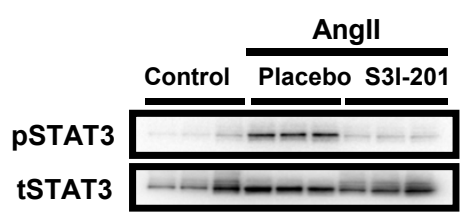

E

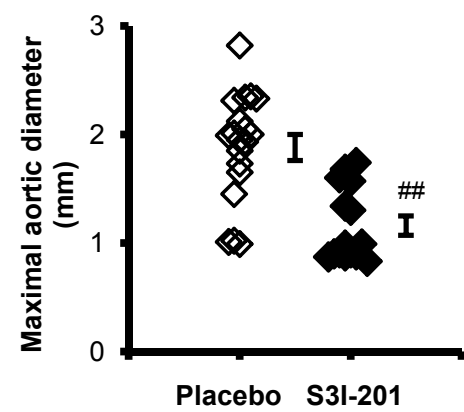

G

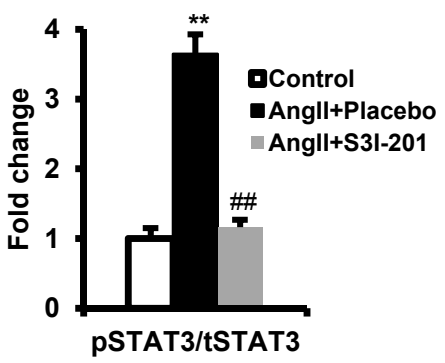


A

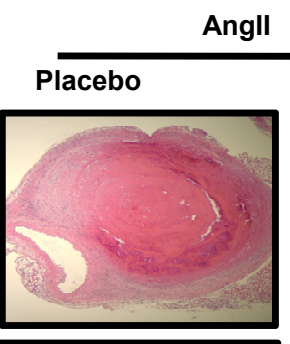

Angll

Fig.2
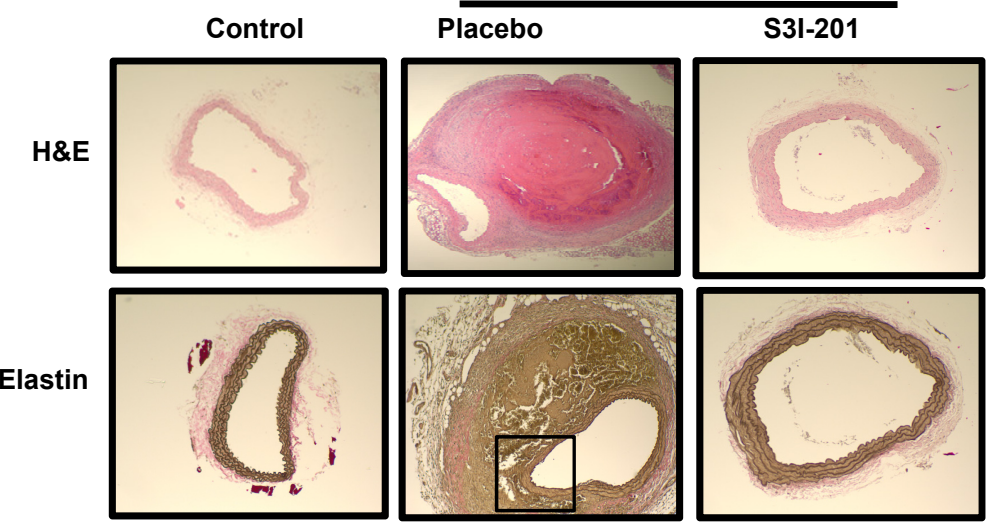

B

C

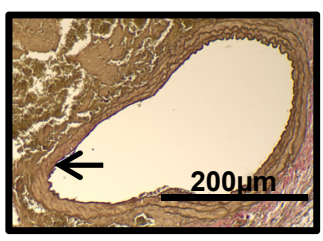

D
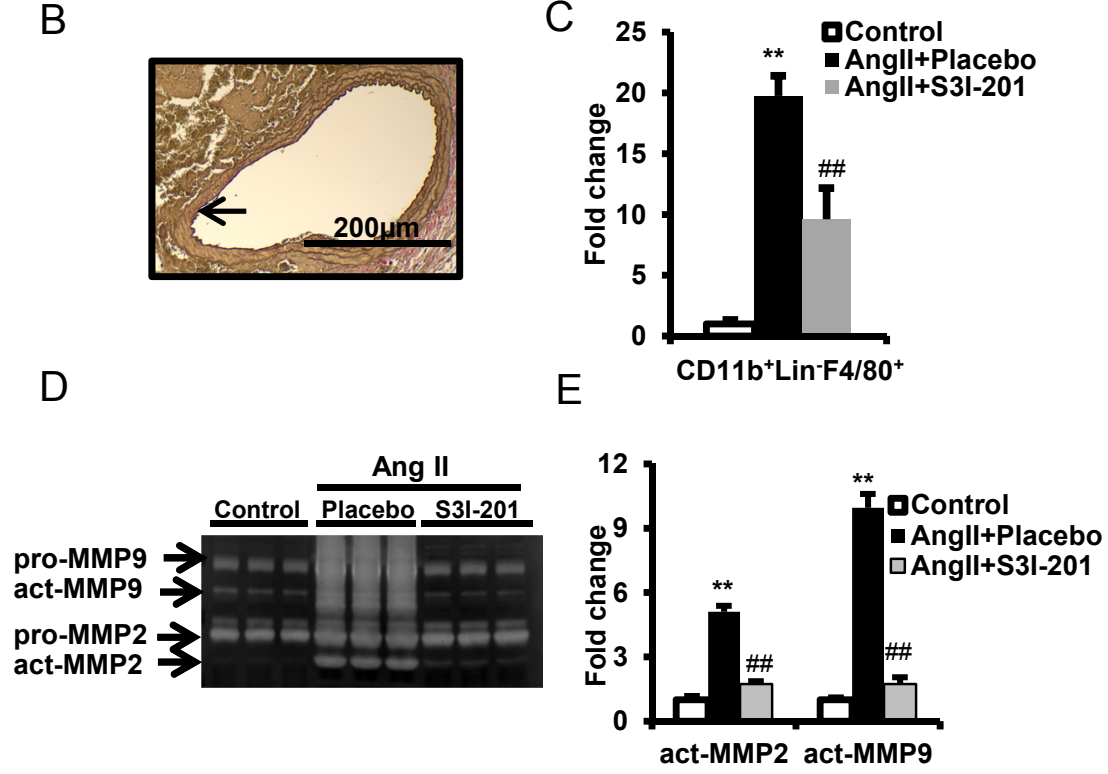
A

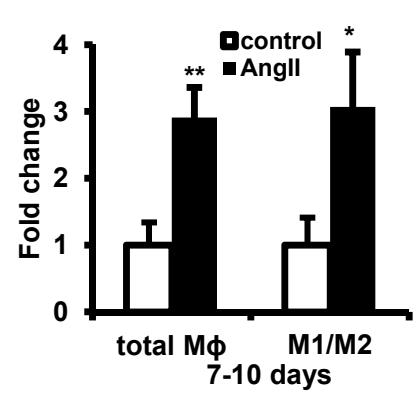

B

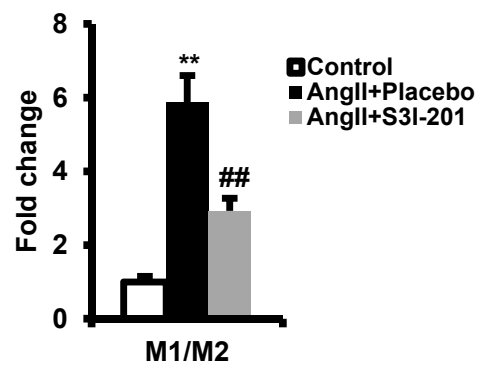

Fig.3

C

Control

Angll+Placebo

Angl|+S3I-201
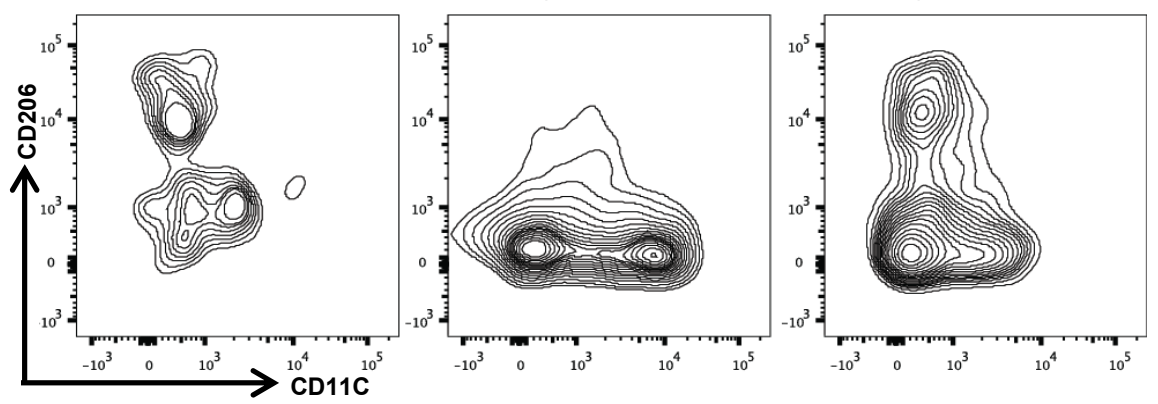

D
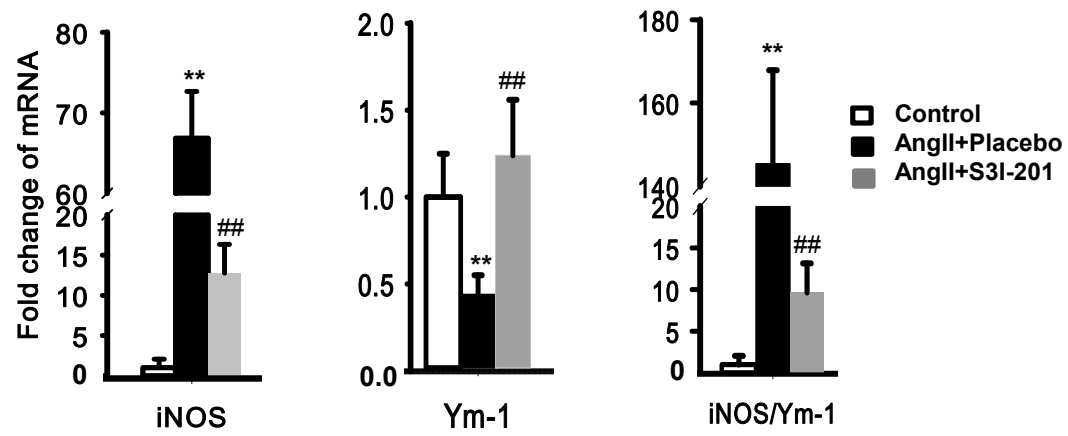
Fig.4

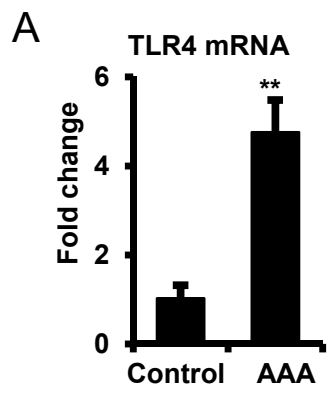

B
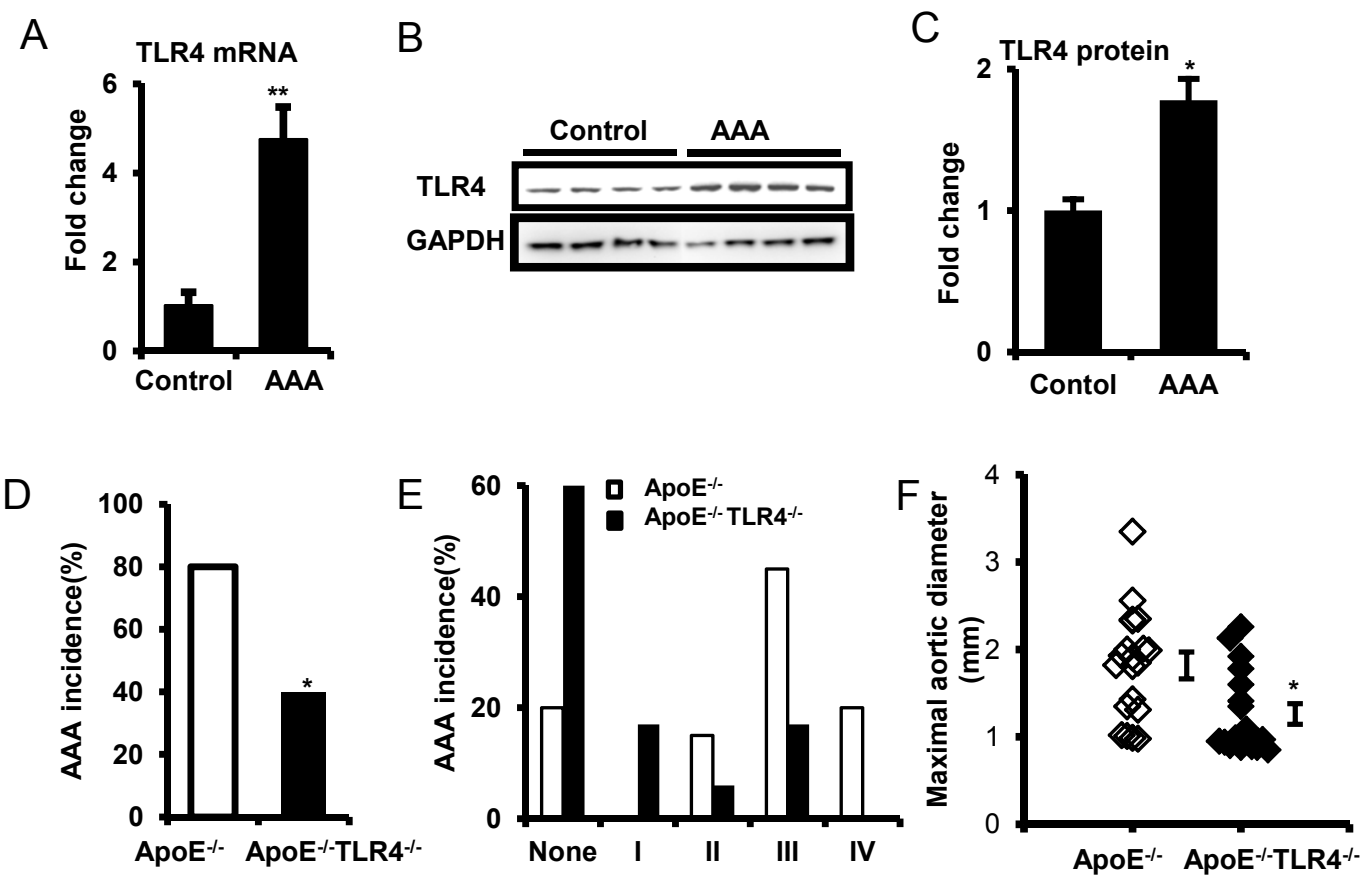
A

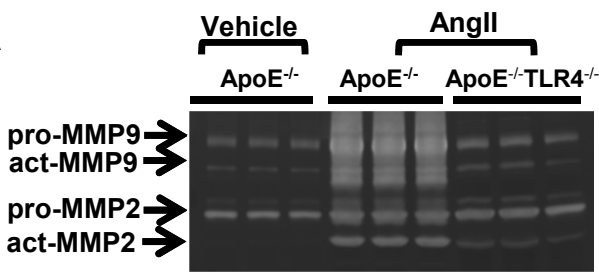

C

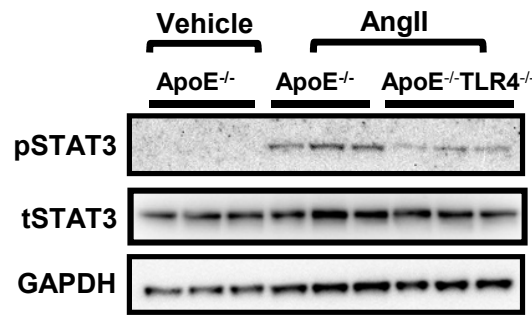

E

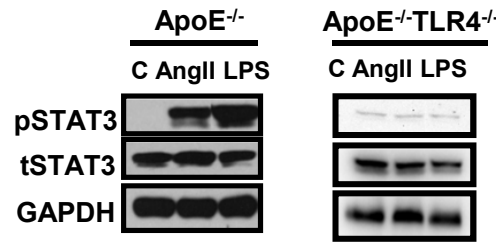

G
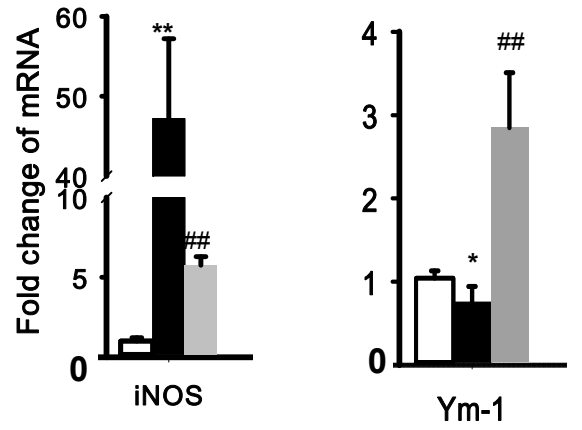

B

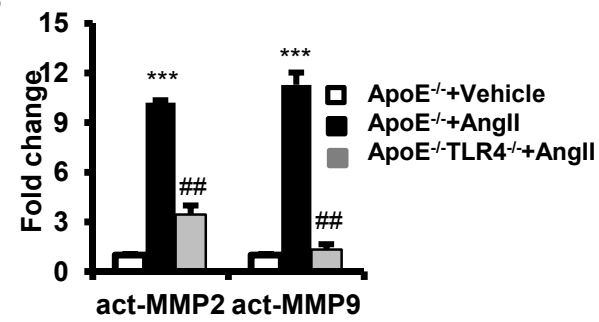

D

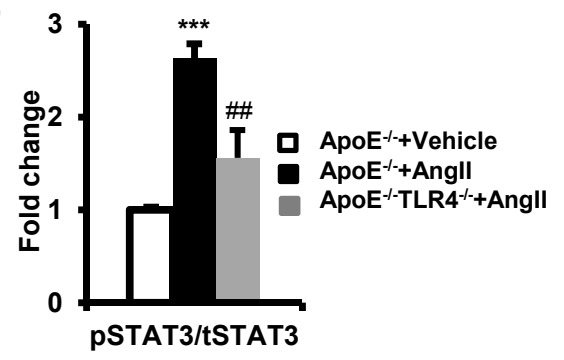

Fig.5
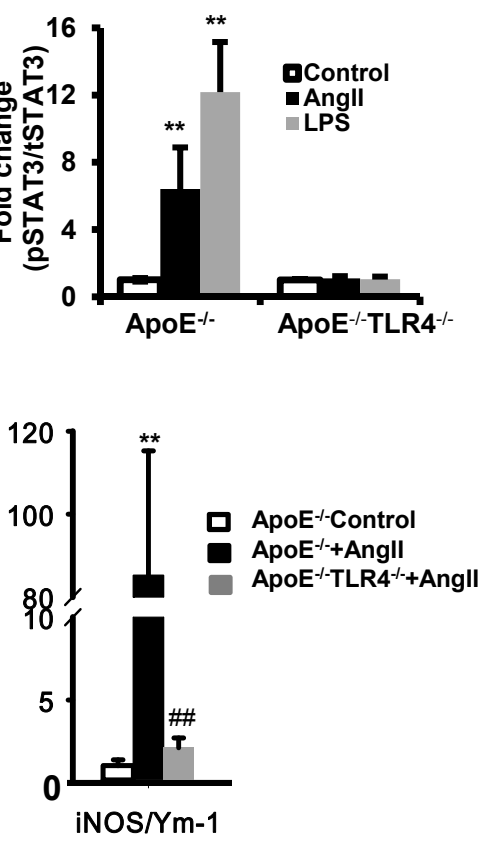
A

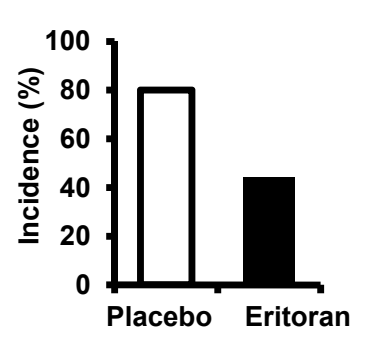

C

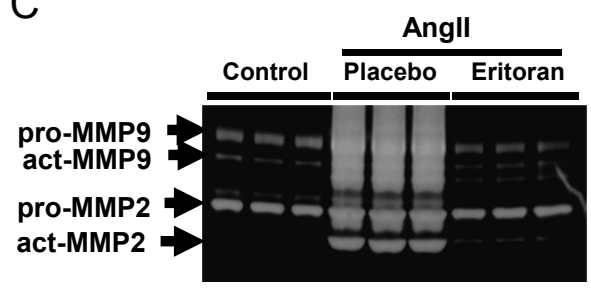

E

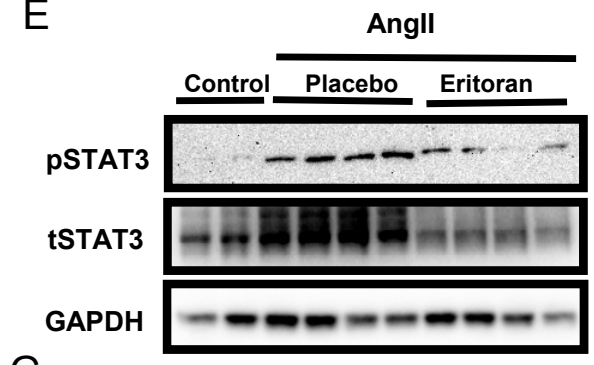

G

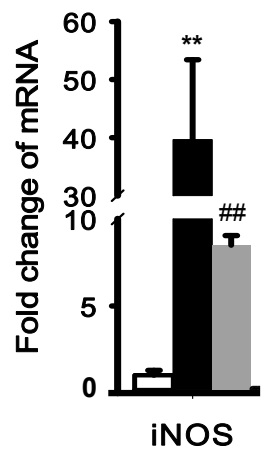

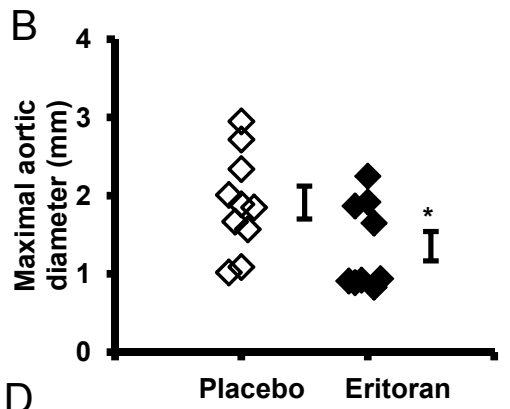

D

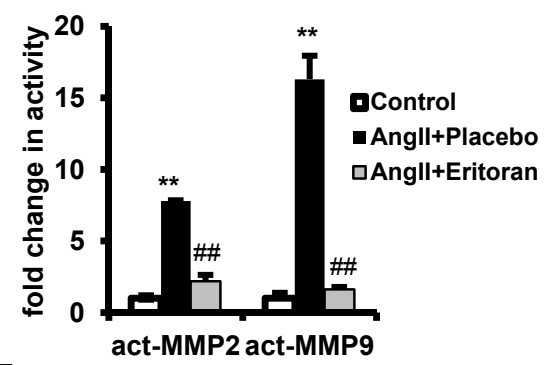

F
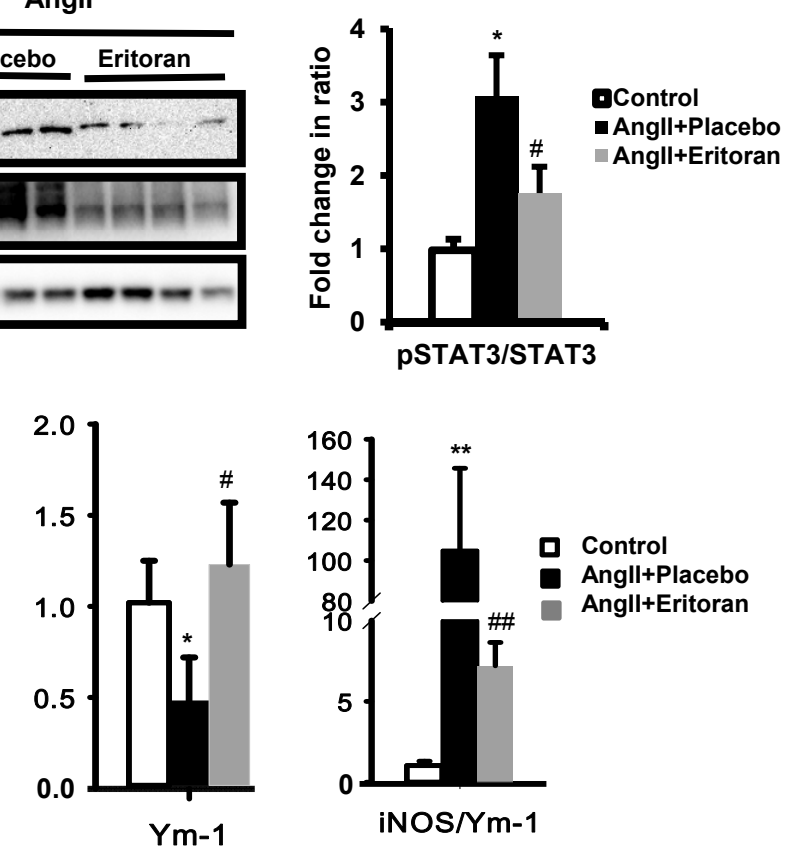

Fig.6 
Fig.7

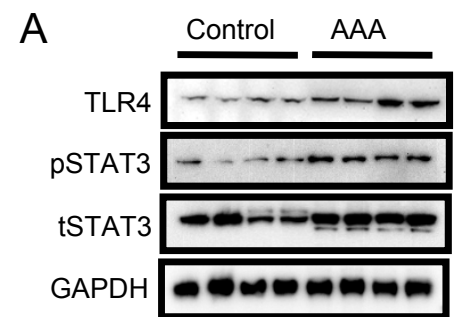

B
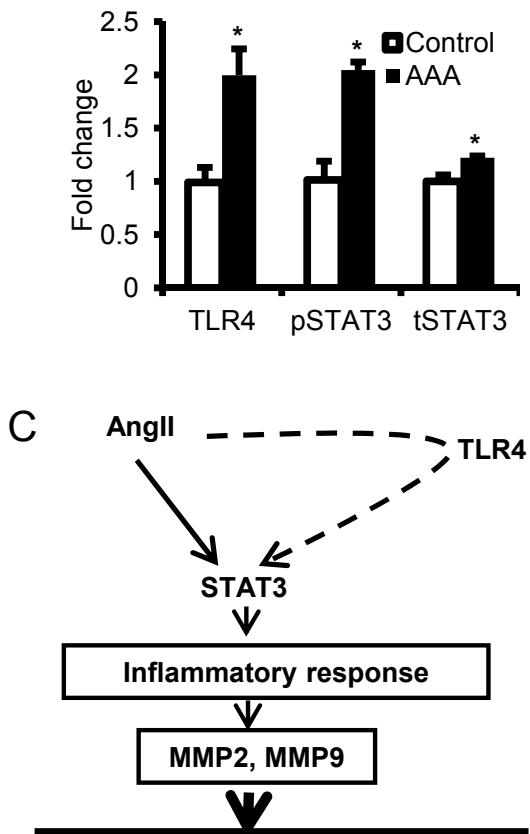

Abdominal Aortic Aneurysm 


\section{Supplemental Material}

\section{Expanded Methods}

\subsection{Determination of blood pressure and lipids}

Systolic blood pressures were measured in trained, prewarmed conscious mice by using a tail cuff apparatus coupled to a PC-based data acquisition system (Kent Scientific Corporation). To avoid procedure-induced anxiety, mice were initially acclimated to the instrument for 3 consecutive days before the actual measurement. On the fourth day, pressures were measured in both the morning and afternoon. Moreover the first 5 of 30 blood pressure values at each session were disregarded, and the remaining 25 values were averaged and used for analysis. ${ }^{1}$ Plasma samples were obtained from individual mice at the time of sacrifice for analysis of cholesterol enzymatically (IDEXX Laboratories).

\subsection{Gelatin Zymography}

MMP-2 and MMP-9 activities in homogenates of aortic tissue or conditioned media from cell cultures were determined by zymography as previously described. ${ }^{2}$ Briefly, gelatin zymography was performed under non-reducing conditions on SDS-PAGE gels containing $1 \mathrm{mg} / \mathrm{ml}$ porcine gelatin. Gel electrophoresis was performed at $150 \mathrm{~V}$ for 1 hour. After electrophoresis, the gel was washed in $2.5 \%$ Triton X-100 solution with gentle agitation for 6 hours at room temperature, followed by replacement with developing buffer containing $50 \mathrm{mM}$ Tris- $\mathrm{HCl}(\mathrm{pH} 7.5), 0.2 \mathrm{M} \mathrm{NaCl}, 5 \mathrm{mM} \mathrm{CaCl}$ and $0.2 \%$ Brij-35). The gel was agitated at room temperature for $30 \mathrm{~min}$, placed in fresh developing buffer, and incubated at $37^{\circ} \mathrm{C}$ overnight. The following morning, gels were stained with $0.5 \%$ Coomassie brilliant Blue R-250 in $40 \%$ methanol and $10 \%$ acetic acid for 2-4 hours and destained in $40 \%$ methanol and $10 \%$ acetic acid at room temperature. Gelatinolytic bands were quantified by scanning densitometry with NIH ImageJ software.

\subsection{Mouse bone marrow derived macrophages (BMDMs)}

Macrophages have been found abundant in aneurysmal tissue, though the source of macrophages infiltrating the abdominal aorta in the pathogenesis of AAAs is unclear. BMDMs were used as an in vitro model for studies of the mechanism of macrophage regulation in response to Angll. BMDMs were obtained by flushing the femurs from either $\mathrm{ApoE}^{-/-}$or $\mathrm{ApoE}^{-/-} \mathrm{TLR}^{-/-}$mice. Cells were cultured as previously described in DMEM containing $10 \%$ heat inactivated FBS and L929-cell conditioned medium at a final concentration of $30 \%(\mathrm{v} / \mathrm{v})$ as a source of granulocyte/macrophage colony stimulating factor which drive the bone marrow monocyte/macrophage progenitors to proliferate towards a greater than $95 \%$ pure population of macrophages. ${ }^{3}$ At Day $7-8$, BMDMs were trypsinized, plated in experimental culture dishes and incubated overnight. Next day, cells were starved in DMEM for 8 hours, and then treated with Angll (0.25-2 $\mu \mathrm{M})$ or LPS (10 ng/mL, List Biological Laboratories Inc., CA) for 16 hours. The medium was collected for MMP assay, and cell lysates for western blot analysis. 


\subsection{Flow cytometry (FACS) analysis}

Aortas were harvested as described and digested following the method of Galkina et al. ${ }^{4}$ Briefly, aortas were minced in $2 \mathrm{ml}$ digestion buffer $(125 \mathrm{U} / \mathrm{ml}$ Collagenase type XI, $60 \mathrm{U} / \mathrm{ml}$ Hyaluronidase type $1-\mathrm{s}, 60 \mathrm{U} / \mathrm{ml}$ DNase I, and $450 \mathrm{U} / \mathrm{ml}$ Collagenase type I, in PBS) and incubated at $37^{\circ} \mathrm{C}$ for one hour with shaking. Cells were filtered, and cell surface staining was performed as previously described ${ }^{5}$ using anti-CD11b (M1/70, BD Pharmingen), anti-CD11c HL3, (BD Pharmingen), anti-CD206 (CO68C2 Biolegend), anti-MHC class II (MS114.15.2, eBioscience), anti-F4/80 (BM8 eBioscience), anti-CD90 (30H12, eBioscience), anti-DX5 (BD Pharmingen), anti-NK1.1 (BD Pharmingen), antiB220 (RA3-6B2, BD Pharmingen) and anti-Ly6G (1A8, Biolegend). All cytometry was performed on a FacsCanto II cytometer (BD Biosciences, San Jose CA), and data were analyzed using FlowJo software (Tree Star, Inc. Ashland OR).

\section{References}

1. Zhang Y, Naggar JC, Welzig CM, Beasley D, Moulton KS, Park HJ, Galper JB. Simvastatin inhibits angiotensin II-induced abdominal aortic aneurysm formation in apolipoprotein E-knockout mice: possible role of ERK. Arterioscler Thromb Vasc Biol 2009;29:1764-1771.

2. Herron GS, Werb Z, Dwyer K, Banda MJ. Secretion of metalloproteinases by stimulated capillary endothelial cells. I. Production of procollagenase and prostromelysin exceeds expression of proteolytic activity. The Journal of biological chemistry 1986;261:2810-2813.

3. Weischenfeldt J, Porse B. Bone Marrow-Derived Macrophages (BMM): Isolation and Applications. CSH protocols 2008;2008:pdb prot5080.

4. Butcher MJ, Herre M, Ley K, Galkina E. Flow cytometry analysis of immune cells within murine aortas. Journal of visualized experiments : JoVE 2011.

5. Jindra PT, Tripathi S, Tian C, lacomini J, Bagley J. Tolerance to MHC class II disparate allografts through genetic modification of bone marrow. Gene therapy 2013;20:478-486. 


\section{Supplemental Table I}

Crosstabulation Table used for Statistical Analysis of Aneurysm Severity by Treatment

\begin{tabular}{|c|c|c|c|c|c|c|c|}
\hline \multirow{2}{*}{ Treatment } & \multicolumn{6}{|c|}{ Aneurysm Type } & \multirow[b]{2}{*}{ total } \\
\hline & & none & Type I & Type II & Type III & Type IV & \\
\hline \multirow{2}{*}{ Angll+Placebo } & Count & 3 & 0 & 3 & 8 & 5 & 19 \\
\hline & $\%$ & 16 & 0 & 16 & 42 & 26 & 100 \\
\hline \multirow{2}{*}{ Angll+S3I-201 } & Count & 9 & 1 & 3 & 2 & 0 & 15 \\
\hline & $\%$ & 60 & 7 & 20 & 13 & 0 & 100 \\
\hline $\begin{array}{l}\text { *Angll+Placebc } \\
\text { †Likelihood Ra }\end{array}$ & $\begin{array}{l}\text { s. Angll+ } \\
\ddagger \text { Goodm }\end{array}$ & \multicolumn{2}{|r|}{$\begin{array}{l}L R \dagger \\
545(\mathrm{P}=0.0\end{array}$} & \multicolumn{2}{|c|}{$\begin{array}{c}T a u \neq \\
0.328(\mathrm{P}=0.029)\end{array}$} & \multicolumn{2}{|c|}{$\begin{array}{c}V \dagger \dagger \\
0.573(\mathrm{P}=0.025\end{array}$} \\
\hline
\end{tabular}

\begin{tabular}{ccccccccc}
\hline \multirow{2}{*}{ Genotype } & \multicolumn{7}{c}{ Aneurysm Type } \\
\cline { 2 - 9 } ApoE-/- & Count & 4 & 0 & 3 & 9 & 4 & 20 \\
\cline { 2 - 9 } & $\%$ & 20 & 0 & 15 & 45 & 20 & 100 \\
\hline \multirow{2}{*}{ ApoE-/-TLR4-/- } & Count & 11 & 3 & 1 & 3 & 0 & 18 \\
\cline { 2 - 8 } & $\%$ & 60 & 17 & 6 & 17 & 0 & 100 \\
\hline & \multicolumn{7}{c}{$L R \dagger$} \\
*ApoE-/- vs. ApoE-/-TLR4-/- & $7.182(\mathrm{P}=0.002)$ & $0.374(\mathrm{P}=0.008)$ & $0.611(\mathrm{P}=0.007)$
\end{tabular}




\section{Supplemental Table II}

Systolic blood pressure and total cholesterol in ApoE ${ }^{-/-}$mice treated with Ang II, S3I-201 and Eritoran, and in Ang II treated ApoE $^{-I}$ TLR4 $^{-I-}$ mice

\begin{tabular}{|c|c|c|c|c|c|c|}
\hline & \multicolumn{4}{|c|}{$\mathrm{ApoE}^{-/-}$} & \multicolumn{2}{|c|}{$\mathrm{ApoE}^{-/-} \mathrm{TLR}^{-/-}$} \\
\hline & $\begin{array}{l}\text { Control } \\
(n=10)\end{array}$ & $\begin{array}{l}\text { Angll } \\
(n=10)\end{array}$ & $\begin{array}{c}\text { Angll+S3I-201 } \\
(n=7)\end{array}$ & $\begin{array}{l}\text { Angll+Eritoran } \\
\qquad(\mathrm{n}=9)\end{array}$ & $\begin{array}{l}\text { Control } \\
(n=10)\end{array}$ & $\begin{array}{l}\text { Angll } \\
(n=10)\end{array}$ \\
\hline $\begin{array}{c}\text { SBP } \\
(\mathrm{mmHg})\end{array}$ & $106 \pm 5$ & $152 \pm 12^{*}$ & $133 \pm 6^{*}$ & $157 \pm 12^{*}$ & $108 \pm 8$ & $151 \pm 9^{*}$ \\
\hline $\begin{array}{c}\text { Total } \\
\text { cholesterol } \\
(\mathrm{mg} / \mathrm{dL})\end{array}$ & $389 \pm 31$ & $395 \pm 59$ & $370 \pm 25$ & $363 \pm 35$ & $305 \pm 33$ & $386 \pm 43$ \\
\hline $\begin{array}{c}\text { Body } \\
\text { weight }(\mathrm{g})\end{array}$ & $29.1 \pm 1.1$ & $30.2 \pm 1.5$ & $28.5 \pm 1.0$ & $29.0 \pm 1.2$ & $29.5 \pm 1.4$ & $30.1 \pm 1.0$ \\
\hline
\end{tabular}

SBP was measured using a tail-cuff system. Total cholesterol and body weight were determined at the end of the study. All results are expressed as mean \pm SEM. ${ }^{*} P<0.05$ compared with control.

\section{Supplemental Table III}

Sequences of primers used for qPCR analysis

\begin{tabular}{|c|l|l|}
\hline Genes & \multicolumn{1}{|c|}{ Forward Primer } & \multicolumn{1}{|c|}{ Reverse Primer } \\
\hline TLR4 & 5'-tggctggtttacacatccatcggt-3' & 5'-tggcaccattgaagctgaggtcta-3' \\
\hline iNOS & 5'-gagacgcacaggcagagg-3' & 5'-caggcacacgcaatgatgg-3' \\
\hline Ym-1 & 5'-cagaaccgtcagacattcatta-3' & 5'-atggtccttccagtaggtaata-3' \\
\hline GAPDH & 5'-tcaacggcacagtcaagg-3' & 5'-actccacgacatactcagc-3' \\
\hline
\end{tabular}




\section{Supplemental Figure 1}

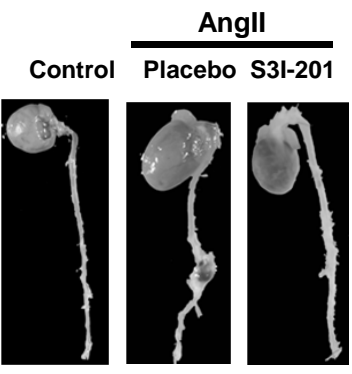

Figure S1 Representative aortas from control, Angll, and Angll+S3I-201 treated $\mathrm{ApoE}^{-/-}$mice. 


\section{Supplemental Figure 2}
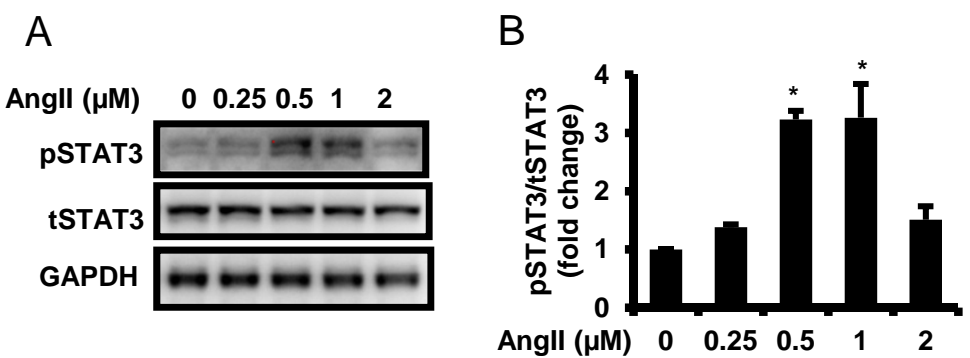

Figure S2 Angll stimulates STAT3 phosphorylation in BMDMs from $\mathrm{ApoE}^{-/-}$mice in a dose-dependent manner. BMDMs were starved in DMEM for 8 hours followed by treatment with the indicated concentrations of Angll for 16h. A. Western blot analysis of pSTAT3 and tSTAT3. B. Densitometric analysis of data in A normalized to GAPDH ( ${ }^{*} P<0.05$ vs. control). 


\section{Supplemental Figure 3}

A

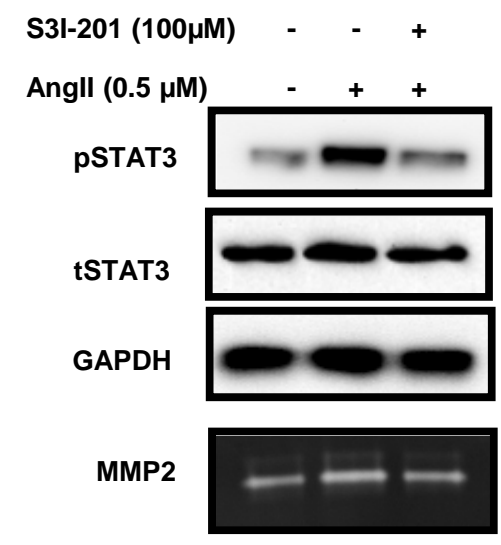

B

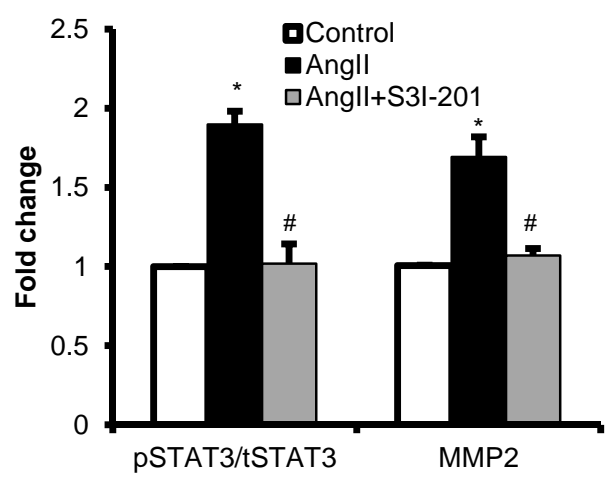

Figure S3 Angll stimulates STAT3 phosphorylation in VSMCs from $\mathrm{ApoE}^{-/}$mice. Furthermore, Ang II stimulation of MMP2 secretion in VSMCs is dependent on pSTAT3. (A) pSTAT3 and tSTAT3 determined by western blot analysis of cell homogenates and MMP2 in the growth medium were determined by zymography. B. Densitometric analysis of data in A normalized to GAPDH $\left({ }^{\star} P<0.05\right.$, compared to control, ${ }^{\#} P<0.05$, compared to Angll, $\mathrm{n}=4$ ). 


\section{Supplemental Figure 4}
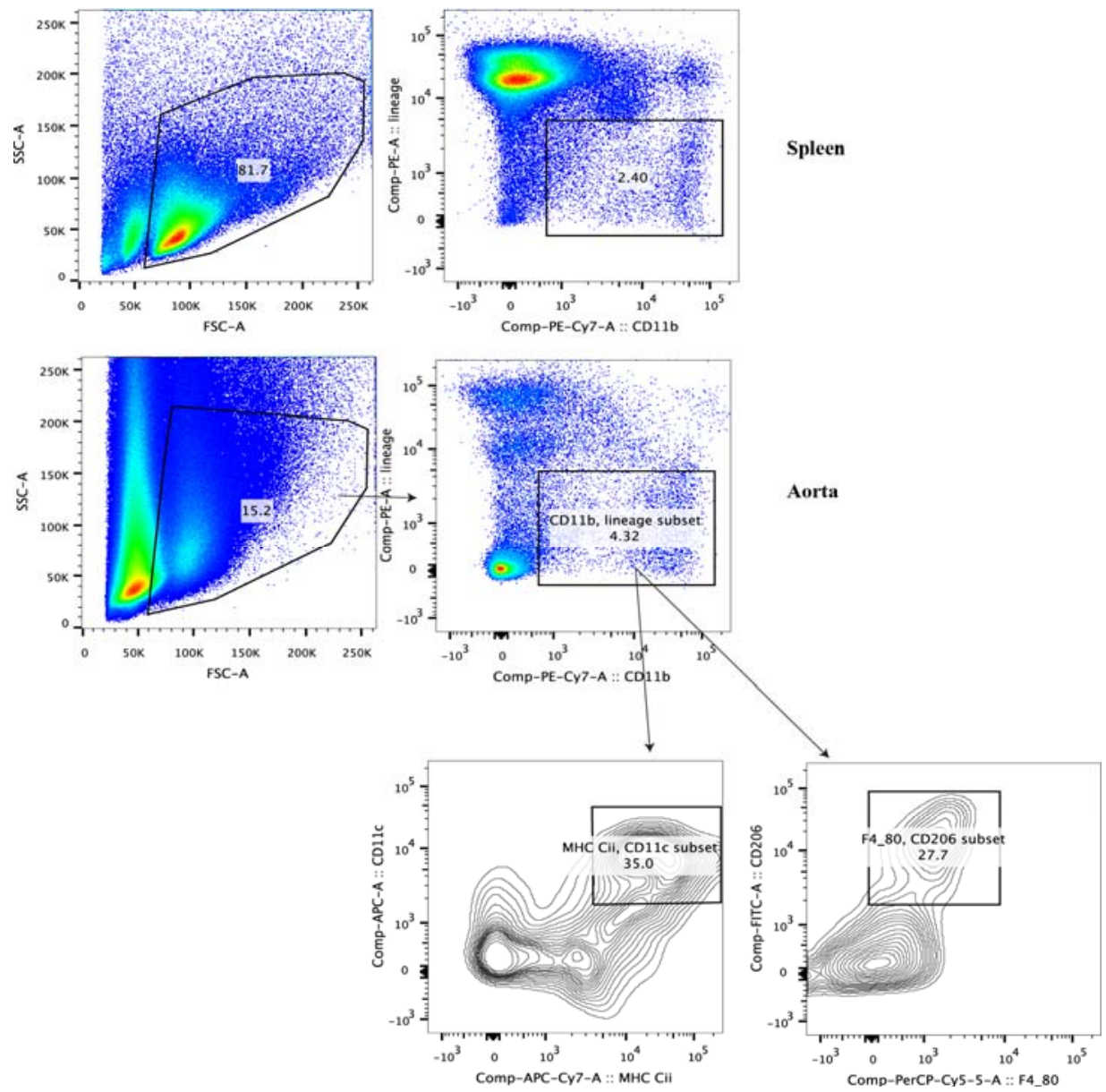

Figure S4 Gating schema for flow cytometric identification of M1/M2 macrophages in aortic digests. Total cells were first gated by forward and side scatter to distinguish lymphocytes in aortic digests. Cells were further gated as shown, for $\mathrm{CD}_{11} \mathrm{~b}^{+} / \mathrm{lin}{ }^{-}$cells. M1 cells were

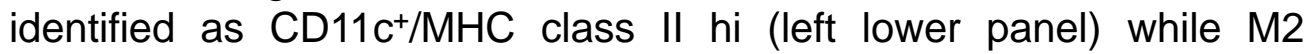
macrophages were identified as CD206+ F4/80 hi (right lower panel). 


\section{Supplemental Figure 5}

A

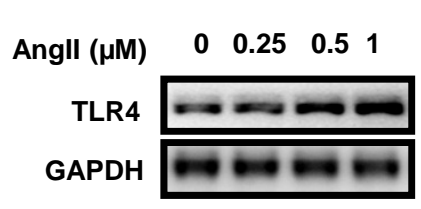

B

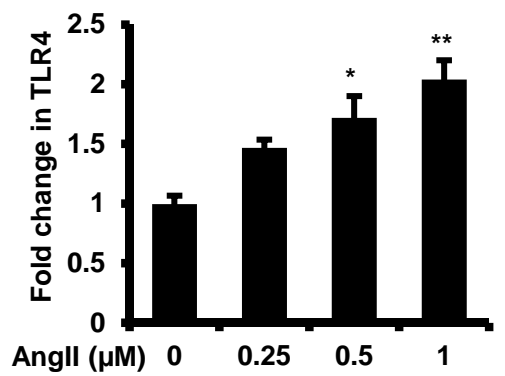

Figure S5 Angll treatment increases levels of TLR4 in BMDMs from $\mathrm{ApoE}^{-/-}$mice in a dose-dependent manner. BMDMs were starved in DMEM for 8 hours followed by treatment with the indicated concentrations of Angll for 16h. (A) Western blot analysis of TLR4 expression, $(B)$ Densitometry scanning of data in A normalized to GAPDH ( ${ }^{\star} P<0.05,{ }^{* *} P<0.01$ vs. control). 


\section{Supplemental Figure 6}

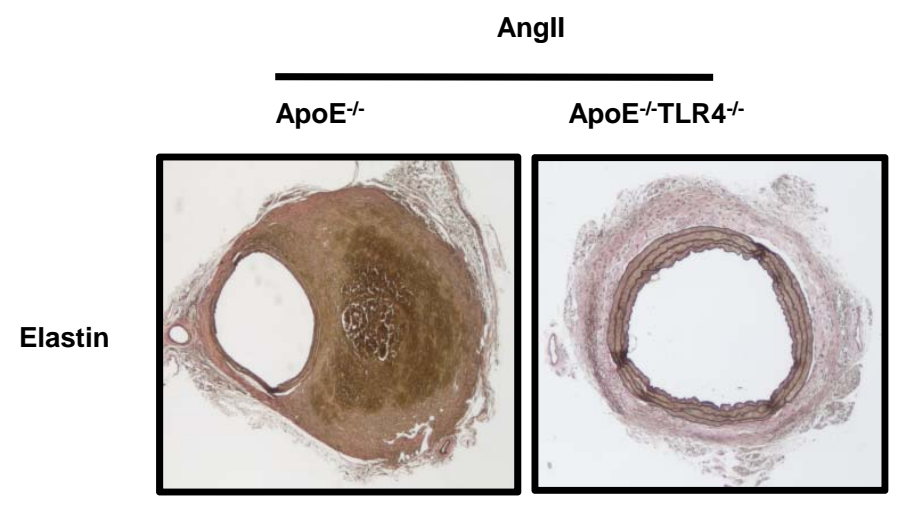

Figure S6 TLR4 knockout attenuates Angll-induced wall thickness in $\mathrm{ApoE}^{-/-}$mice 


\section{Supplemental Figure 7}

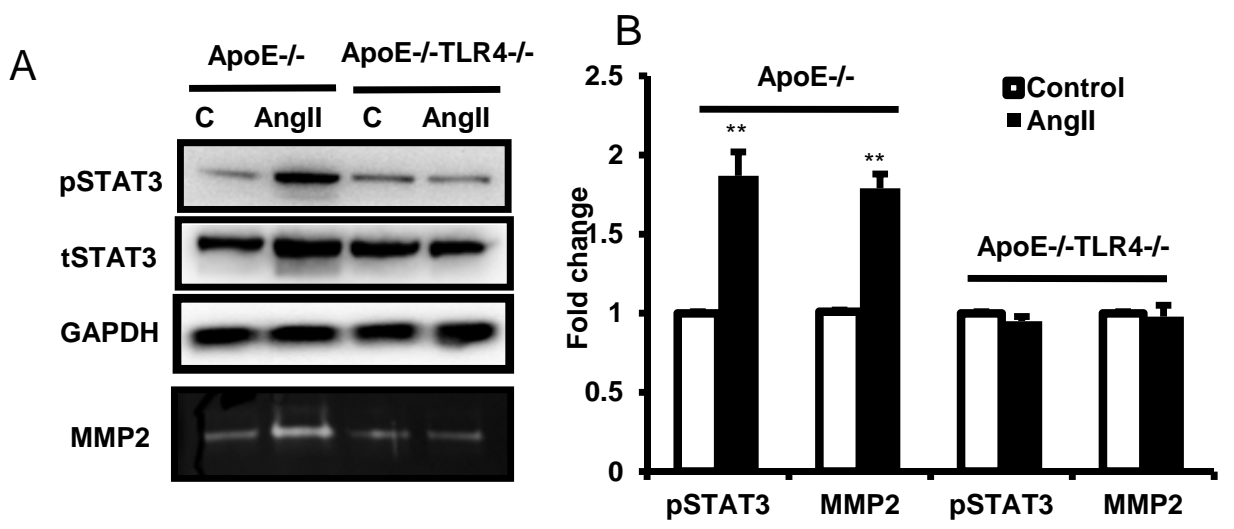

Figure S7 TLR4 knockout attenuates Angll-induced STAT3 phosphorylation and MMP2 activity. (A) pSTAT3 and tSTAT3 determined by western blot analysis of cell homogenates and MMP2 in the growth medium were determined by zymography. B. Densitometric analysis of data in A normalized to GAPDH $\left({ }^{\star \star} P<0.01\right.$, compared to control, $\left.\mathrm{n}=4\right)$. 